\title{
Republic of Belarus: Financial Sector Assessment Program- Detailed Assessment of Compliance-Basel Core Principles for Effective Banking Supervision
}

This Detailed Assessment of Compliance-Basel Core Principles for Effective Banking Supervision for the Republic of Belarus was prepared by a staff team of the International Monetary Fund as background documentation to the Financial Sector Assessment Program with the member country. It is based on the information available at the time it was completed in January 2006. The views expressed in this document are those of the staff team and do not necessarily reflect the views of the government of the Republic of Belarus or the Executive Board of the IMF.

The policy of publication of staff reports and other documents by the IMF allows for the deletion of market-sensitive information.

To assist the IMF in evaluating the publication policy, reader comments are invited and may be sent by e-mail to publicationpolicy@imf.org.

Copies of this report are available to the public from

International Monetary Fund $\bullet$ Publication Services

700 19th Street, N.W. • Washington, D.C. 20431

Telephone: (202) 6237430 • Telefax: (202) 6237201

E-mail: publications@imf.org • Internet: http://www.imf.org

Price: $\$ 15.00$ a copy

International Monetary Fund Washington, D.C. 
FINANCIAL SECTOR ASSESSMENT PROGRAM

REPUBLIC OF BELARUS

DETAILED ASSESSMENT OF COMPLIANCE

BASEL CORE PRINCIPLES FOR

EFFECTIVE BANKING

SUPERVISION

JANUARY 2006

THE WORLD BANK

FinANCIAL SECTOR VICE PRESIDENCY

EUROPE AND CENTRAL ASIA REGIONAL

VICE PRESIDENCY
INTERNATIONAL MONETARY FUND

MONETARY AND FINANCIAL SYSTEMS

DEPARTMENT 


\section{Contents}

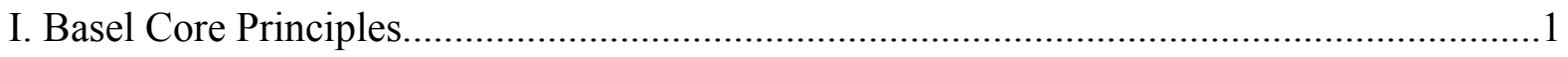
A. General....
B. Summary of the Basel Core Principles for Effective Supervision Assessment ........4
C. Principle-by-Principle Assessment .......................................................................

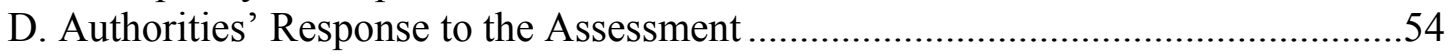

\section{Tables}

1. Detailed Assessment of Compliance of the Basel Core Principles...................................9

2. Summary Compliance of the Basel Core Principles........................................................52

3. Recommended Action Plan to Improve Compliance of the Basel Core Principles.............53 


\section{Basel Core Principles}

\section{A. General}

1. This detailed assessment of Observance with the Basel Core Principles for Effective Banking Supervision is the first external comprehensive assessment of the system of banking supervision in Belarus. The assessment was conducted by Árpád Király, Hungarian Financial Supervisory Authority, and Walter Zunic, World Bank Consultant, in November 2004. The National Bank of the Republic of Belarus (NBRB) cooperated fully with the assessment team and provided extensive clarification in the form of documents and oral explanation. Their assistance is gratefully acknowledged.

\section{Information and methodology used for the assessment}

2. The NBRB was requested to complete a self-assessment and a questionnaire in advance of the mission. In preparing this report, the assessors have used the assessment methodology prescribed in the Guidance Note on Assessment of Implementation of the Basel Core Principles for Effective Banking Supervision. And, following the recommendations of the Basel Committee, the assessment was carried out by two persons, both with extensive banking supervision experience. During the mission, the self-assessment observance of the standards and principles was clarified and checked through subsequent discussion with the authorities and market participants in critical areas. The two assessors reviewed documents made available in advance of the mission, spent several days interviewing representatives of the NBRB, and commercial bankers, in order to clarify and/or verify the facts contained in the self-assessment.

3. The assessment of observance of each of the Core Principles follows a qualitative approach and is based on the Core Principles Methodology Document (October 1999). The assessment method consisted of examining the degree of observance of each of a principle's essential criteria and, where the assessors judged necessary, of the additional criteria, too. In conducting this assessment, the two assessors made extensive reference to the relevant legislation governing bank licensing, banking activity and on-going supervision of banks in the Republic of Belarus, particularly the Law of the Republic of Belarus of October 3, 2000 "On the Banking Code of the Republic of Belarus" (Banking Code), Edict 320 of June 13, 2001 on the approval of the Statute of the National Bank of the Republic of Belarus and the Rules and Instructions issued by the National Bank of the Republic of Belarus. The assessment included a review of the relevant, legally non-binding instruments of the NBRB under the form of "Recommendations", the internal Provisions of the NBRB, the licensing documents and the bank examination reports prepared by the NBRB, annual reports, the NBRB website and other relevant material. The assessment was also based on the selfassessment prepared by the NBRB and discussions with staff in the banking supervision area, and with banks. The authorities were very cooperative and helpful in facilitating this assessment. The self-assessment report prepared by the authorities was comprehensive, the authorities made available an extensive range of information in the assessment process and 
the assessors had unrestricted access to staff of the Banking Supervision Department (BSD) of the NBRB.

\section{Institutional and macroprudential setting, market structure overview}

4. The legal framework for the regulation and supervision of the financial sector has undergone significant reform during the last decade. The result has been the adoption of a series of laws and regulations that are reasonably comprehensive and broadly consistent with international best practices. The Belarus regulatory policies are formulated on two levels. At the first level is The Law of the Republic of Belarus of October 2000 "On the Banking Code of the Republic of Belarus" (BC), that is the main legislative act which regulates banks, providing the statutory and legal framework for banking and banking supervision in Belarus, and this level also include decrees issued by the President. The NBRB has substantial influence in the process of drafting of laws. At the second level and on more technical policy, the NBRB has the powers to issue prudential regulations for enforcing provision of the BC. The NBRB issues Regulatory Legal Acts jointly with the Government, Rules, and Instructions, which complete the framework of minimum prudential standards that banks must meet.

5. The NBRB fulfills its responsibilities of authorization, supervision, and regulation of banking institutions operations through the Banking Supervision Directorate. The Banking Supervision functions at the NBRB are carried out by the Banking Supervision Department (BSD) and staff located at the six regional Main Departments of the NBRB. (The regional Units of the BSD are not reflected in the organizational chart below.)

6. The BSD examiners at the Head Office of the NBRB, primarily examine the Head Offices of all the banking institutions located in Minsk. The examination of the branches of these banks is conducted by the Minsk Regional Office and by the examiners located at the other five regional branches. The banks established in the free economic Zones (FEZ) are also examined by the Head Office examiners of the NBRB.

7. The Department's main objective is to: analyze the financial condition of the banks, the risks taken by management, the adequacy of the internal control system, adherence to established prudential requirements, accuracy of accounting transactions, and reliability of reports submitted to the NBRB.

8. The BSD consists of 62 specialists, inspectors and analysts located at the NBRB headquarters in Minsk. A further 67 staff who undertake supervision of branches are located throughout the 6 regional NBRB branches.

9. The on-site supervision activities are carried out by the Inspection Department, which consist of three Divisions: (a) the Asset Quality Assessment and Profitability Division; (b) the Capital adequacy and Liquidity Inspection Division; and (c) the Administration and Risk Management Assessment Division. 


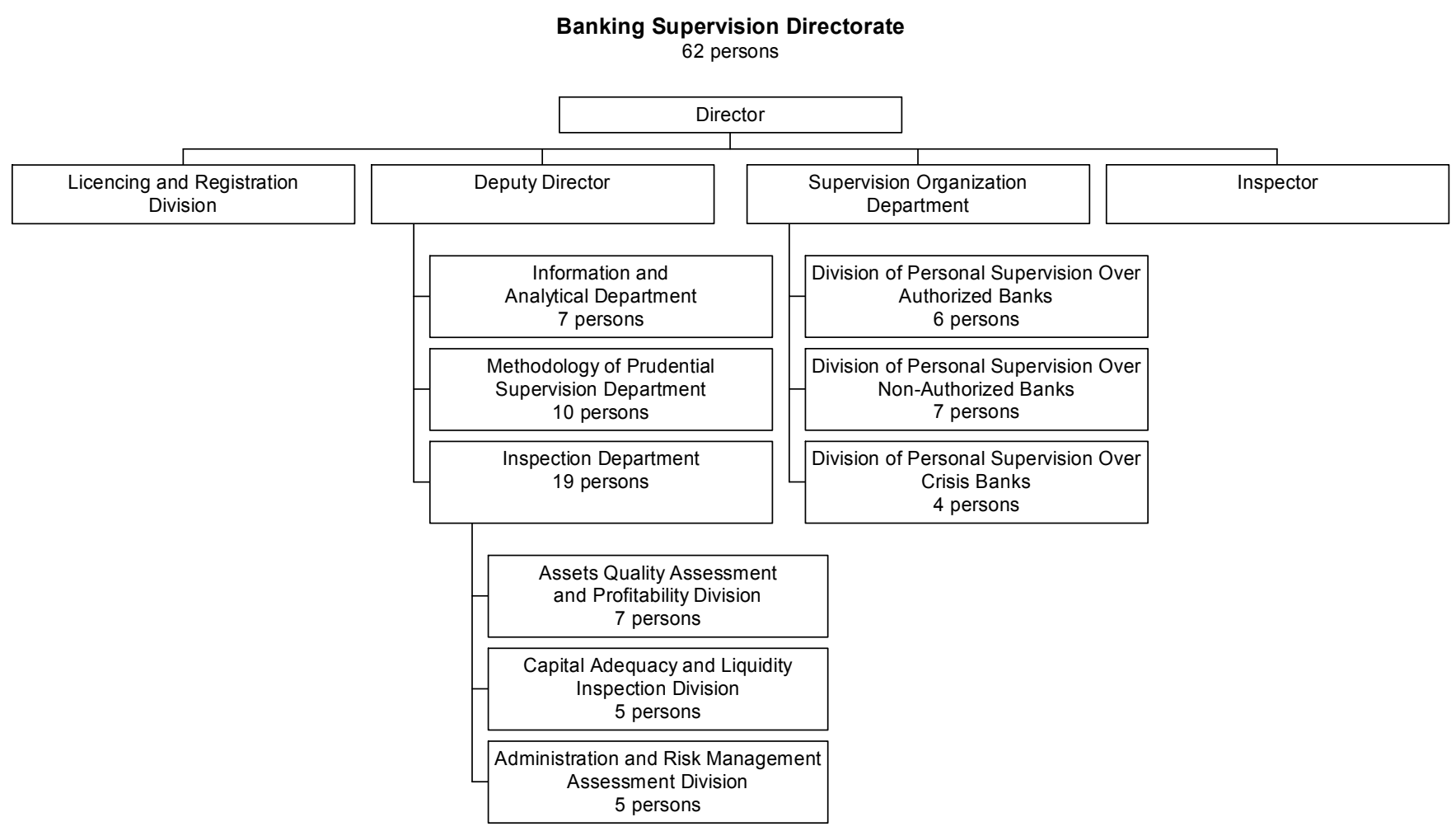

10. Off site supervision is conducted by Supervision Organization Department that also cosists of three Divisions: (a) Division of Personal Supervision over Authorized Banks; (b) Division of Personal Supervision Over Non Authorized Banks; and (c) Division of Personal Supervision over Crisis Banks.

11. These two Departments are complemented by the Licencing and Registration Division, and the Departments of Information and Analysis and Methodology of Supervision Department.

\section{General preconditions for effective banking supervision}

12. Belarus has experienced improvements in stabilizing its economy in recent years, however the macroeconomic situation continues difficult.

13. The concentration in the Belarusian banking system is high: the six large banks make up about 85 percent of the total assets and 83 percent of the total capital of the banking system. Of the 6 systematically important banks (SIBs) 5 are exclusively or mainly state owned. The largest, the main domestic savings bank, accounts for about 41 percent of the assets, and holds 63 percent of retail deposits.

14. The SIBs are authorized for participation in state programs, involving recommended lending to priority sectors, programs and companies on preferential terms. Such loans are 
often guaranteed by central or local governments and/or recommended by Presidential or Government Decrees. Due to the lack of a level playing field, the six largest banks are able to offer loans below market prices and thus crowd out their competitors from the market. The smaller banks have to find a niche to operate in the market. The non-competitive market environment and the frequently changing rules of game discourage foreign investors from entering in the market.

15. The Supervisory authority should not be an owner of any institution it has the obligation to supervise. Political influence is exerted on decisions of banks through the presence of government officials on the supervisory boards.

16. The NBRB is implementing the IFRS standards for financial institutions on a stage by stage basis and so far has introduced eleven national standards of financial reporting based on international standards. The process of implementing in full international standards will be accomplished by 2006.

17. In order to avoid systemic bank crises the NBRB, in addition to its function of supervising banks, by law is charged with the function of creditor of last resort for banks and supports the liquidity of the banking system by operating in the inter bank market.

Management has indicated that in emergency cases measures can be applied to sustain private depositor's confidence in the banking system.

\section{B. Summary of the Basel Core Principles for Effective Supervision Assessment}

\section{Preconditions for effective banking supervision (CP 1):}

18. The Statute of the NBRB defines that among its objectives is the developing and strengthening the banking system of the Republic of Belarus. The various provisions of the $\mathrm{BC}$ cover among others the registration and issuing of licenses of banks and nonbank financial and credit institutions, regulating their activities, and exercising continuous control over observance of banking law by banks and nonbank financial and credit institutions. The NBRB fulfills its responsibilities of authorization, supervision, and regulation of financial institutions operations through the Banking Supervision Directorate (BSD). The BSD performs both offsite and onsite supervision.

19. Institutional arrangements weaken the Director of the Bank Supervision Directorate and the Director lacks autonomy. At the NBRB, the rank of Director is a third-level position in relation to the Board of NBRB. The Head of Bank Supervision, who is a member of the Board of Directors, refers matters of importance to a one of the Deputy Governors who in addition to Bank Supervision is also responsible for Foreign Currency Directorate and Legal Directorate, and who is a member of the Board of the National Bank. Given the importance of bank supervision and the fact that as the economy of the country continues to grow and more commercial banks are incorporated in the system, it would be appropriate to increase the autonomy of this function by giving the position of Head of Bank Supervision more visibility and authority within NBRB. 
20. The legal protection for supervisors is currently not addressed. No law provides for legal protection for the supervisory agency and its staff for actions taken while discharging their duties in good faith. There is no formal NBRB indemnification policy protecting employees against the costs of defending their actions while discharging their duties.

21. Coordination among different agencies is not formalized. The cooperation with the State Securities Commission and Insurance Supervisory Department of the MoF is not formalized, and the meetings and information exchange between the two authorities are not on a regular basis.

\section{Licensing and structure (CPs 2-5):}

22. The Banking Code clearly specifies that the name of a bank must include the word "Bank". Prior to engaging in banking operations, each institution is required to obtain a license from the NBRB which is the sole authority for granting banking licenses. The Banking Code grants the right to the NBRB to request information about the founders, to assess their financial condition and to evaluate the professional fitness of executive bodies and the chief accountant. Under the provisions of the Banking Code, the NBRB has the authority to grant authorization for acquisitions or increases of qualifying holdings in an existing bank. However, bank ownership approval by the NBRB is limited to shareholdings of 10 percent or higher, causing a situation where the BSD is not aware of the full extent of financial interests of some shareholders.

\section{Prudential regulation and requirements (CPs 6-15):}

23. Rules and regulation regarding capital adequacy generally conform to the Basel Capital Accord 1988, and as of January 1, 2005 will include a capital charge for market risk, country risk, foreign exchange risk and other material risks.

24. Rules and regulations covering requirements of criteria, practices and procedures for extension of credit are adequately addressed by the regulations issued by the NBRB. The procedure for classifying the assets of a bank exposed to credit risk and the procedures for establishing special loss reserves for assets exposed to credit risk are mandated by regulations issued by NBRB.

25. The current asset classification system consists of 4 risk groups with provision requirement ranging from 0 percent for the Standard loan category, and then jumping to a provision of 30 percent for the next classification category. Doubtful and loss assets are classified at 50 percent and 100 percent respectively.

26. The sudden increase from a zero percent asset provision allocation to a 30 percent asset provision for a classified credit is considered high by international standards. The NBRB should create a new loan category that would require a 10 percent provision. In addition, the NBRB should establish a general provision covering all loans of 2 percent in order to cover any unexpected deterioration in the country's economic situation. 
27. Decision making by banks in credit operations is evaluated by the NBRB to ensure compliance with the Banking Code, according to which banks must be independent in their activities and they must independently determine the condition of transaction not conflicting with the legislation. However, in practice banks often are not completely independent in their decisions to issue credits. Frequently, regulations signed by the President and Government of the Republic of Belarus requires banks to allocate their resources to programs with a social orientation. Experience shows that such credits are at times extended to insolvent enterprises, which ultimately causes solvency and liquidity problems to the banks and causes the Government to have to periodically allocate new resources to the banks.

28. State and local government policies should not be funded by the banks, and banks should not be pressured to enter into lending transactions at terms that are not in compliance with the internal polices of the institution and the supervisory regulations.

29. The NBRB has issued regulations covering criteria for identifying a bank's related customers in accordance with the dispositions of the Banking Code, and for the most part banks conduct investment operations within the limits of the Regulations. However there have been instances where Agencies of the Government have opted not to take corrective actions against a bank for violations of the Regulations. Again, these decisions are made in connection with the importance to the State of the measures to which these credits are granted. These operations are carried out by the large State banks. Such practices should be eliminated and a uniform approach should be taken in evaluating the financial condition and risks of banks

30. The National Bank of the Republic of Belarus has issued regulations and recommendations requiring banks to have in place systems that accurately measure and monitor country risk, market risk, foreign exchange risk and all other material risk. The Instruction on Economic Standards for Banks becomes effective January 1, 2005. The effectiveness of the implementation of this instruction, that affects the assessment of BCPs 11,12 , and 13 , cannot be analyzed at the present time.

31. The main functions of controlling compliance with requirements of the Law "On Measures to Prevent Legalization of Criminal Proceeds" are not assigned to the NBRB but to the Ministry of Taxes and Duties and the State Control Committee of the Republic of Belarus. Bank supervisors need to place more emphasis on detection, deterrence, and reporting of suspicious transactions. Financial intelligence needs to be centralized in a single agency and provisions for international cooperation need to be strengthened.

\section{Methods of ongoing supervision (CPs 16-20):}

32. CPs 16, 18 and 19 are assessed as largely compliant and CP 17 is assessed as Compliant. The NBRB conducts full scope on-site examinations of banks including their larger branches on a two year basis. The examination process is comprehensive and covers a wide range of banking areas, including risk management systems, internal controls, management systems, compliance with prudential requirements, and asset quality and 
provisioning. Two examination reports are prepared at the completion of each full scope examination and forwarded to management. There is also a comprehensive system of off-site monitoring of banks, involving the analysis of a wide range of information provided to the NBRB by banks on a monthly and quarterly basis (with some information provided at more frequent intervals).

33. CP 20 is assessed as Non-compliant since the NBRB does not conduct consolidated supervision. The NBRB has prepared a draft in order to introduce amendments to the BC. The draft introduces definitions of a banking group and a bank holding company, and allows NBRB the possibility for supervising such groups and holding companies on a consolidated basis. Adoption of the proposed amendment to the BC will allow the NBRB to develop and introduce the necessary mechanisms of supervision of the activities of banking groups and holding companies on a consolidated basis.

\section{Accounting standards (CP 21):}

34. The NBRB has not introduced International Financial Reporting Standards (IFRS) to the full extent. Introduction of IAS standards for financial statements of the banks should move expediently forward.

\section{Formal powers of supervisors (CP 22):}

35. The Banking Code empowers the NBRB to issue the necessary decisions to restore the rightful conditions and remove abuses, develop a practice of corrective action and early intervention. The Banking Code provides a range of remedial actions, including the removal of the bank's governor and withdrawal of the bank's license.

\section{Cross-border banking (CPs 23-25):}

36. The Banking Code does not provide the NBRB with the means to conduct the supervision of credit institutions on a global consolidated basis over banking entities. The authority to perform consolidated supervision of banks with consideration for foreign subsidiary legal entities and investments in foreign banks is not codified in the legislation. Foreign banking institutions are subject to similar regulatory requirements applicable to all other banks operating in Belarus. The current legal provisions give the NBRB powers to access any information on a subsidiary of a foreign banking institution in Belarus.

\section{Principle-by-Principle Assessment}

37. The following assessment of the Basel Core Principles (BCP) is based on the Core Principles Methodology of the Basel Committee on Banking Supervision, October 1999. The methodology makes a distinction between "essential" and "additional" criteria. Essential criteria should be present in order for supervision to be considered effective. Additional criteria further strengthen supervision and countries should strive to implement as many of 
the additional criteria as possible. This assessment takes both the essential and additional criteria into consideration.

38. The Basel Core Principles are grouped into seven categories: (1) Preconditions for Effective Banking Supervision; (2) Licensing and Structure; (3) Prudential Regulations and Requirements; (4) Methods of Ongoing Banking Supervision; (5) Information Requirements; (6) Formal Powers of Supervisors; and (7) Cross-border Banking.

39. A principle will be considered compliant whenever all essential criteria are generally met without any significant deficiencies. There may be instances where a country can demonstrate that a principle is observed through different mechanisms. Conversely, due to the specific conditions in individual countries, the essential criteria may not always be sufficient to achieve the objective of the principle and, therefore, other measures (including any additional criteria) may also be deemed necessary by the assessor to judge that compliance is achieved. A principle will be considered largely compliant whenever only minor shortcomings are observed, which do not raise any concerns about the authority's ability and intent to achieve full compliance with the principle within a prescribed period of time. A principle will be considered materially non-compliant whenever, despite progress, the shortcomings are sufficient to raise doubts about the authority's ability to achieve compliance. A principle will be considered non-compliant whenever no substantive progress toward compliance has been achieved. A principle will be considered not applicable whenever, in the view of the assessor, the CP does not apply given the structural, legal, and institutional features of a country. 
Table 1. Detailed Assessment of Compliance of the Basel Core Principles

\begin{tabular}{|c|c|}
\hline Principle 1. & $\begin{array}{l}\text { Objectives, Autonomy, Powers, and Resources } \\
\text { An effective system of banking supervision will have clear responsibilities and objectives for } \\
\text { each agency involved in the supervision of banks. Each such agency should possess } \\
\text { operational independence and adequate resources. A suitable legal framework for banking } \\
\text { supervision is also necessary, including provisions relating to the authorization of banking } \\
\text { establishments and their ongoing supervision; powers to address compliance with laws, as } \\
\text { well as safety and soundness concerns; and legal protection for supervisors. Arrangements } \\
\text { for sharing information between supervisors and protecting the confidentiality of such } \\
\text { information should be in place. }\end{array}$ \\
\hline Principle 1(1) & $\begin{array}{l}\text { An effective system of banking supervision will have clear responsibilities and objectives for } \\
\text { each agency involved in the supervision of banks. }\end{array}$ \\
\hline Desc & 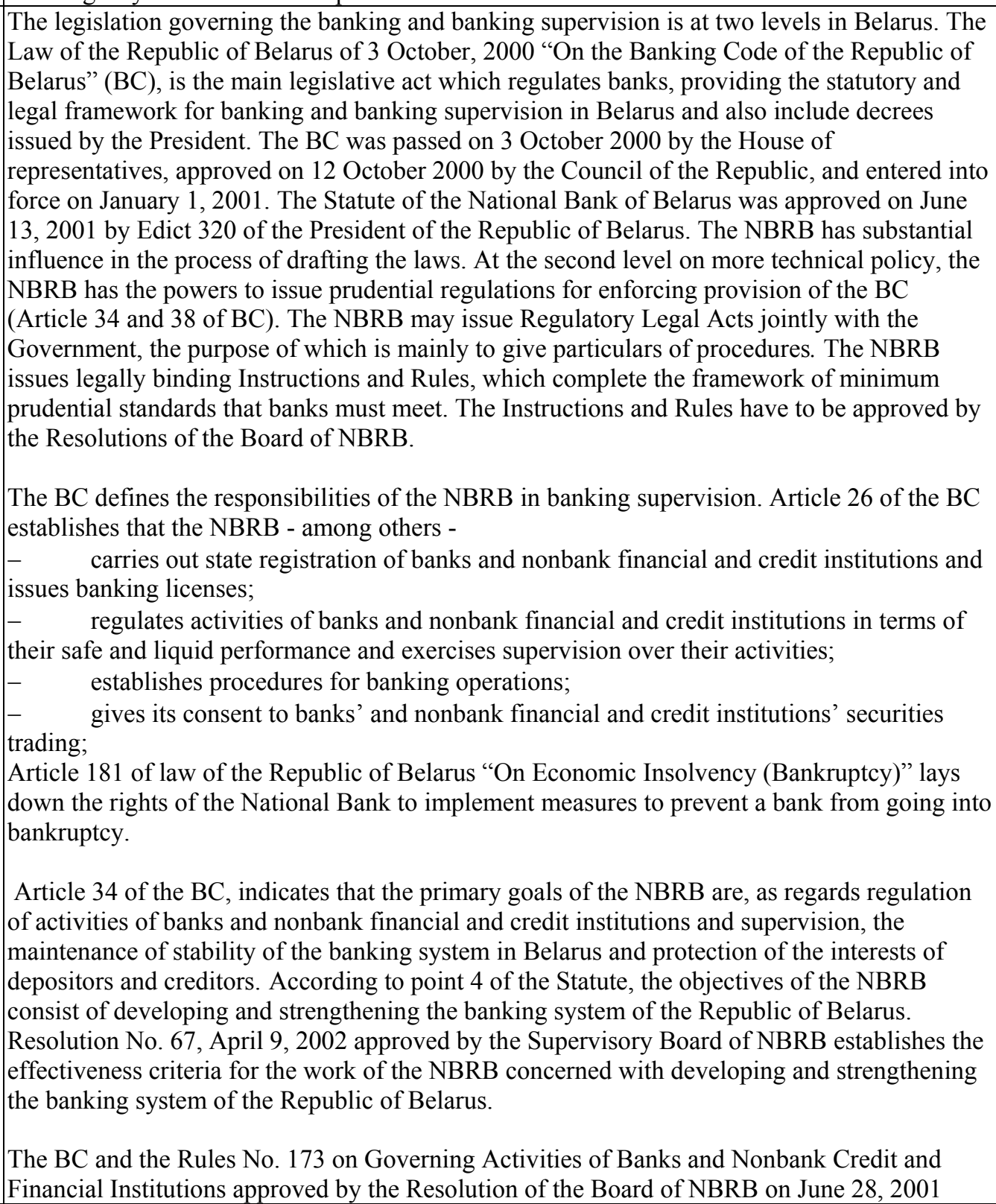 \\
\hline
\end{tabular}


(Rules No. 173) provide a framework of minimum prudential standards that banks must meet. (This regulation has been amended recently (approved by the Resolution of the Board of the national Bank of the Republic of Belarus on June 26, 2004) and will come into force on $1^{\text {st }}$ of January 2005.)

Article 112 of the $\mathrm{BC}$ authorizes the NBRB to establish the following prudential requirements ("economic standards") for banks:

- minimum size of the authorized fund for a newly established (reorganized) bank;

- minimum size of ownership capital (equity) for an operating bank;

- limit for non-monetary portion of the authorized fund;

- liquidity standards;

- capital adequacy standards;

- maximum risk per client (or a group of interrelated clients);

- maximum risk per insider and persons associated therewith;

- maximum size of major risks;

- standard for bank participation in investment activities;

- foreign exchange risk standard (open currency position);

- maximum risk per creditor/depositor;

- maximum size of a bank's liabilities on bills of exchange; and

- maximum size of funds deposited by natural persons.

As the NBRB is the sole banking supervisory body in the Republic of Belarus, there is no need for an arrangement for coordination among organizations involved in banking supervision.

However, by Edict No. 673 of November 15, 1999 “On Certain Measures for Improving Coordination of Activities of Control Agencies of the Republic of Belarus and the Procedure of Their Invocation of Economic Sanctions", the Council for Coordination of Control Activities in the Republic of Belarus was created in order to coordinate the activities of state agencies and other organizations authorized by law to conduct inspections of financial and economic activities of legal entities and sole proprietors, which includes the NBRB. The NBRB two times a year submits proposals to the Coordination Council regarding inspections of banks jointly with other control agencies. As a rule, specialists of the Procuracy, the State Control Committee (SCC), the Ministry of Taxes and Duties, and other institutions and organizations take part in joint inspections. The results of joint inspections are reviewed comprehensively, taking in consideration the opinions of all parties that took part in an inspection. The work of the NBRB and the SCC is coordinated to a certain degree by way of review of the activities of banks at meetings of a joint working group of the SCC and the NBRB, consisting of their deputy directors and other representatives of these organizations.

Article 135 of the BC and Article 181of the Law on Bankruptcy lay down the instances where the NBRB acts to prevent crises in banks and the related powers, which include requiring a bank to remedy identified violations, implementing corrective actions of influence and constraints, requiring reorganization, revoking licenses, and filing with the court for institution of bankruptcy proceedings. According to Article 52 of the BC, the NBRB may act as lender of last resort for banks, providing them with credit assistance to maintain their liquidity, if such a measure is necessary for keeping the banking system functioning soundly.

Laws and supporting regulations on banking activity are updated. Frequently. The BC was adopted in 2000, it was modified in 2002 and a draft amendment, submitted by the NBRB, is before the parliament. The Instructions and Rules are amended regularly.

The objectives of the NBRB are set out in the BC (Article 25) and in the Statute (Point 4.).In accordance with Article 46 of the BC the National Bank undergoes audits each year by an auditing organization specified by the President of Republic of Belarus. In addition, interagency inspections of the NBRB's activities are conducted periodically by the order of the 


\begin{tabular}{|c|c|}
\hline & $\begin{array}{l}\text { Republic of Belarus President by representatives of the SCC, ministries, and other bodies of } \\
\text { state government and administration. } \\
\text { Information on the status of the banking sector is accessible to the public on the NBRB's } \\
\text { official website, and in the NBRB's official publications). Furthermore, the Supervisory Board } \\
\text { of the NBRB adopted the Resolution No. 176, June 28, 2001 "On Approving the Rules on } \\
\text { Releasing Information Used to Assess the Soundness of a Bank and a Nonbank Credit and the } \\
\text { Finance Institution, and on the Content of Released Information", which regulates the } \\
\text { procedure for release of information by banks. }\end{array}$ \\
\hline Assessment & Compliant. \\
\hline Comments & $\begin{array}{l}\text { The legislation meets every essential and additional criteria. However, the way of coordination } \\
\text { between the different agencies raises questions with regard the responsibilities. Although, the } \\
\text { NBRB is the sole authority in banking supervision, it is somehow subordinated to the } \\
\text { Coordination Council and especially to the SCC, which heads the Coordination Council. The } \\
\text { NBRB is required to submit its inspection plan to the Coordination Council and answer its } \\
\text { questions. In practice, the SCC does not change the plan. In the Coordination Council, as a } \\
\text { rule, the sharing of information on activities of banks is limited in scope. However, the NBRB } \\
\text { at the request of the SCC is obliged to send final reports on the violation of laws. Emergency } \\
\text { issues must be discussed with the SCC. In case of bankruptcy, there is a consultation between } \\
\text { the NBRB and the SCC, albeit the approval of the SCC is not needed to initiate bankruptcy } \\
\text { proceedings. The NBRB's activities are reviewed periodically by the order of the Republic of } \\
\text { Belarus president by representatives of the SCC, and other bodies of the state. }\end{array}$ \\
\hline Principle 1(2) & Each such agency should possess operational independence and adequate resources. \\
\hline Description & 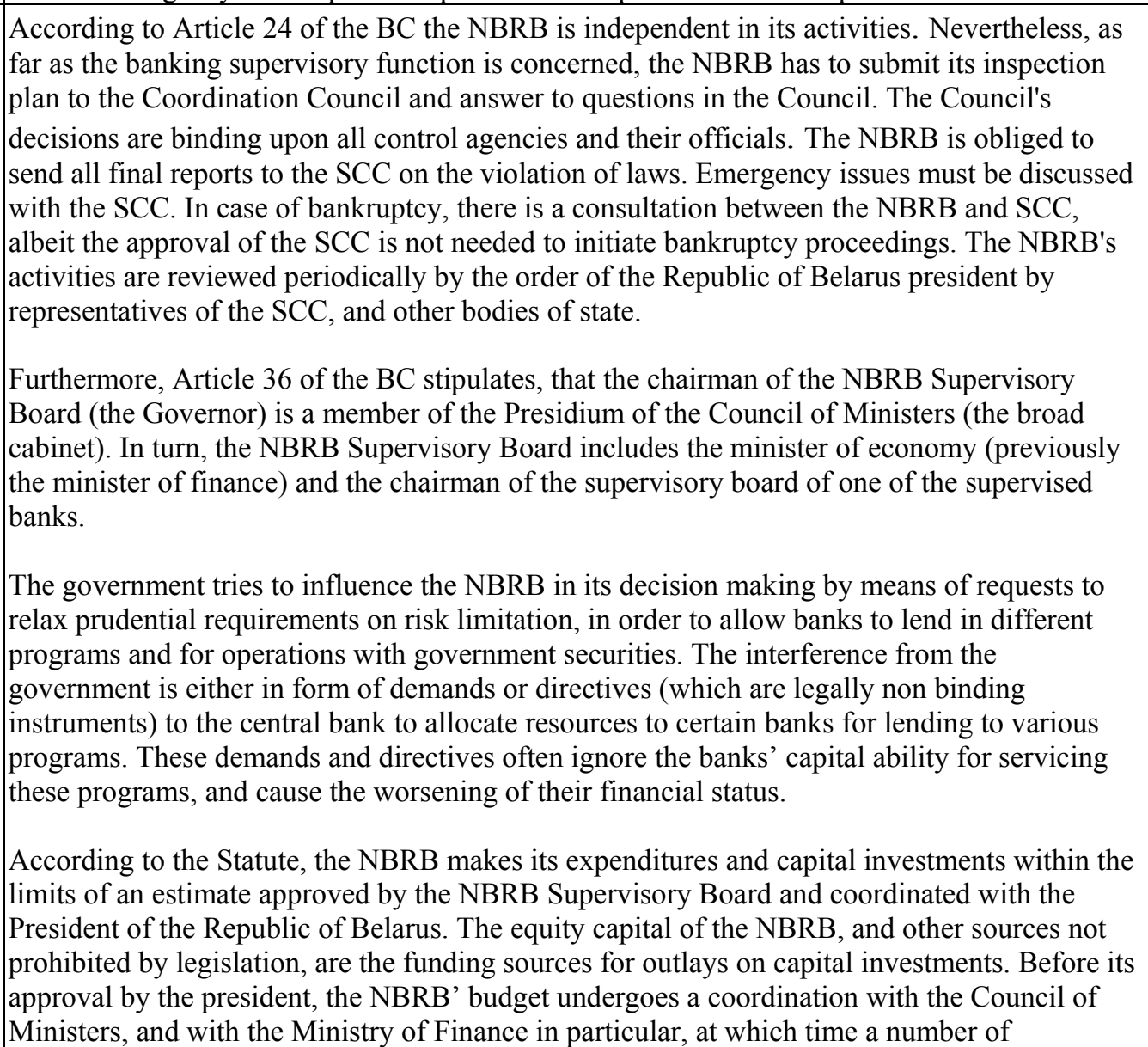 \\
\hline
\end{tabular}


corrections are made, which undermines the financial independence of this banking supervisor from the government.

The employees of NBRB enjoy the status of civil service employees, hence the laws related to civil service employees are applicable to them. The employees of NBRB are required to comply with the requirements of the Law "On Principles of Service in the State Apparatus". Persons whose professional training is inconsistent with qualification requirements and persons with non-clarified or unremitted charges are not allowed to hold positions in the state apparatus. Employees are required to keep state and bank secrets, observe the rules of work ethics, and keep required qualifications current, and they are prohibited from engaging in entrepreneurial activity, accepting gifts and compensation, using official information they receive for personal gain, and fulfilling the directives and orders of political parties. These requirements are included in the Statute and also in the employee contract in order to guarantee professionalism and honesty of personnel.

The funding of banking supervision allows effective supervision of banks within the framework of current legislation (e.g., the NBRB has to conduct onsite inspections in the banks in every third year, however it has opted to do inspections every second year.) When evaluating the resources for supervisory work, it should be taken into account, that the BSD is only one of the 14 directorates of the NBRB. Its staff is 62, although there are a further 67 staff at the regional offices who participate in the supervision of bank branches. As the BSD is part of the NBRB, certain functions are centralized e.g., training, maintenance, etc. Within the NBRB the Financial and Budgetary Directorate prepares the budgetary plan and the Board of the NBRB discusses and approves the draft budget. The draft - after consultation with the MoF and other agencies - is approved by the President of the Republic.

Salaries at the NBRB are similar with those in the government ministries. Small changes are envisaged, depending on the proposals on regulating the labor compensation of NBRB employees, which have to be submitted by other state agencies. Currently the BSD has a staff of 62 persons at head quarters, compared to the 47 persons 3 years ago. This increase in personnel shows the commitment of the NBRB's management to allocate adequate resources for banking supervision. The fluctuation in labor force is not high, albeit it exists.

The law permits the use of external experts in the inspections. Although the NBRB occasionally gives mandate to auditors in special examinations at the cost of banks, it is not the practice of NBRB to do so.

The NBRB has a training center outside Minsk. According to a provision, each employee of the NBRB has to be trained every second year. Every 6 months, there is seminar on banking supervision in the training center. The NBRB also relies upon the training programs of other central banks (mainly on the Russian Federation), and international financial institutions. Lack of command of English language is a real obstacle, however the employees can be trained in Russian, especially in the central bank of Russia. The NBRB is member of the Group of Banking Supervisors of Central and East Europe, and participates in their seminars. The NBRB subscribed for the FSI connect, which runs approximately 70 interactive on-line courses a year.

The BSD does not have its own budget for training, which is part of NBRB's training program.

The BSD is well equipped, there is no lack of computers and other electronic equipment, which would slow down the review of the banking industry.

The BSD conducts on-site inspections in the branches allocated throughout the 6 regions of the country, with the 67 staff members in the branches who report to the BSD. 


\begin{tabular}{|c|c|}
\hline & $\begin{array}{l}\text { The chairman and the members of the NBRB Supervisory Board are appointed in accordance } \\
\text { with Article } 61 \text { of the BC by the President of the Republic of Belarus, with the approval of the } \\
\text { Council of the Republic of the Republic of Belarus National Assembly, for a term of five } \\
\text { years. The President of the Republic of Belarus has the right to dismiss the chairman and (or) } \\
\text { members (a member) of the National Bank Supervisory Board upon notification of the Council } \\
\text { of the Republic of the Republic of Belarus National Assembly in cases of prescribed in Article } \\
62 \text { of the BC. There is no provision on the public disclosure of the reason for dismissal. } \\
\text { However in the case of the Chairman of the Board the reasons are more or less obvious or a } \\
\text { public disclosure would occur. In the case of the Head of BSD, if the Chairman of the Board of } \\
\text { NBRB decides on his removal, no formal procedure is prescribed, only the general regulation } \\
\text { and the contract of the Head of BSD has to be taken into account. The Head of BSD in not } \\
\text { protected in any way. }\end{array}$ \\
\hline Assessment & Materially non compliant \\
\hline Comments & $\begin{array}{l}\text { The assessment reflects, that the present arrangements of responsibilities between the } \\
\text { controlling authorities weaken the operational independence of the NBRB in supervisory } \\
\text { issues, the activity of NBRB is under permanent government control. As a member of the } \\
\text { government and a representative of the industry are seated in the main decision making body } \\
\text { of the NBRB, the decision making on individual cases and the implementation of the } \\
\text { prudential aspects of the regulations can not be guaranteed. The government may significantly } \\
\text { influence the budget of the NBRB, as the NBRB before submitting its budget to the President } \\
\text { of the Republic has to coordinate with the Ministry of Finance. There are signs of interference } \\
\text { into the operational independence of the NBRB both from the side of the government and the } \\
\text { industry. As far as supervisory issues are concerned, this takes the form of demands and } \\
\text { directives. }\end{array}$ \\
\hline Prin & $\begin{array}{l}\text { A suitable legal framework for banking supervision is also necessary, including provisions } \\
\text { relating to authorization of banking establishments and their ongoing supervision. }\end{array}$ \\
\hline De & $\begin{array}{l}\text { The legal framework of banking supervision is described in the BC. Article } 18 \text { stipulates, that } \\
\text { the State regulates the operation of banks and nonbank financial and credit institutions through } \\
\text { different tools. These are the following: } \\
- \text { government registration of banks and nonbank financial and credit institutions; } \\
-\quad \text { licensing banking activities; } \\
-\quad \text { imposing bans and restrictions on operation of banks and nonbank financial and credit } \\
\quad \text { institutions; } \\
-\quad \text { setting economic standards for banks and nonbank financial and credit institutions; } \\
\quad \text { identification of banking law violations and application of sanctions provided by the } \\
\quad \text { BC and other laws of the Republic of Belarus; and } \\
\quad \text { identification of cases of handling banking transactions without proper license and } \\
\quad \text { application of punitive measures to persons responsible for such transactions. } \\
\text { Articles } 77 \text { and } 92 \text { clarify, that the state registration of banks shall be carried out by the NBRB } \\
\text { and a license for banking operation shall be issued by the NBRB. The NBRB also has the } \\
\text { power to withdraw a banking license. (BC, Article } 97 \text { ) } \\
\text { According to Article } 38 \text { of the BC, the NBRB is entitled to issue regulatory legal acts, that are } \\
\text { binding upon central bodies of state administration, bodies of local administration and self- } \\
\text { government, all banks and nonbank credit and finance institutions, other legal entities } \\
\text { operating in Belarus, and natural persons. These acts of the NBRB do not change the laws and } \\
\text { may not be in conflict with laws or with the edicts. According to Article } 34 \text { of the BC the } \\
\text { NBRB shall regulate activities of banks and nonbank financial and credit institutions. } \\
\text { Article } 37 \text { of the BC states, that banks and nonbank credit and finance institutions operating in } \\
\text { Belarus must submit financial and economic information and documentation required by the }\end{array}$ \\
\hline
\end{tabular}




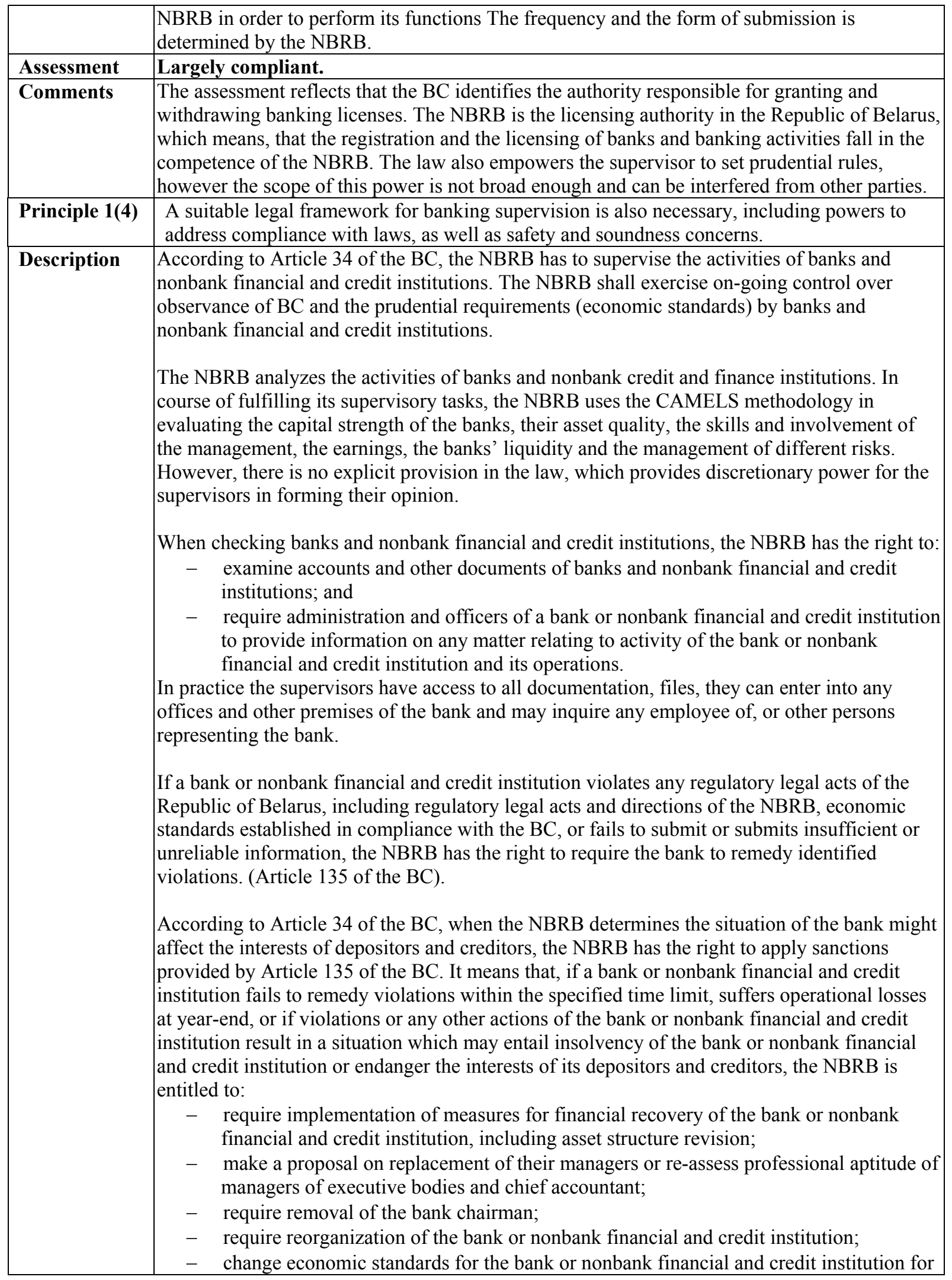




\begin{tabular}{|c|c|}
\hline & $\begin{array}{l}\text { up to one year or until violations are remedied; } \\
\text { - } \\
\text { impose a ban on opening subsidiaries (branches) and organizational units located off } \\
\text { the premises of the bank or nonbank financial and credit institution for up to one year } \\
\text { or until violations are remedied; } \\
\text { - } \quad \text { suspend the license for specific banking transactions for up to one year or until } \\
\text { violations are remedied; } \\
-\quad \text { revoke the license for specific banking transactions; and } \\
\text { - } \quad \text { commit the bank or nonbank financial and credit institution to temporary management } \\
\text { of the NBRB or appoint temporary management in the manner prescribed by } \\
\text { legislation of the Republic of Belarus. } \\
\text { The NBRB is entitled to apply administrative sanctions to executive officers of the bank or } \\
\text { nonbank financial and credit institution in compliance with legislation of the Republic of } \\
\text { Belarus. The NBRB has the right to impose fines without contest from a bank or a nonbank } \\
\text { credit and finance institution. } \\
\text { Article } 97 \text { of the BC lists the cases, when the revocation (or suspension) of the banking license } \\
\text { may take place. }\end{array}$ \\
\hline Assessment & Largely compliant. \\
\hline Comments & $\begin{array}{l}\text { The NBRB has ample power to address compliance of banks with laws. The NBRB has } \\
\text { access to any information or person in the banks. However, when the supervisory decisions are } \\
\text { being formulated, the NBRB has limited right to apply qualitative judgments, the decisions on } \\
\text { taking corrective actions are made on the basis of formalized criteria. Furthermore the } \\
\text { legislation does not specify clearly, that corrective actions may be taken against banks on the } \\
\text { basis of the reasoned judgments of the supervisor. In relation to safety and soundness } \\
\text { concerns, the NBRB is not authorized to determine conditions, which could lead to insolvency } \\
\text { of the bank or endanger the interests of its depositors and creditors, although this is one of the } \\
\text { criteria to take corrective measures against a bank. The law has not been granted the right for } \\
\text { the NBRB to require from banks the reporting of assets, liabilities, and equity capital in line } \\
\text { with the supervisor's assessment. In case of this, the NBRB only can recommend to the bank to } \\
\text { reflect in the bank's supervisory returns (reports) the judgment of NBRB based on qualitative } \\
\text { criteria. }\end{array}$ \\
\hline Principle 1(5) & $\begin{array}{l}\text { A suitable legal framework for banking supervision is also necessary, including legal } \\
\text { protection for supervisors. }\end{array}$ \\
\hline Description & $\begin{array}{l}\text { The status of NBRB's employees is established by the legislation, namely by the Republic of } \\
\text { Belarus Law No. 2581-XII, November } 23,1993 \text { "On the Principles of Service in the State } \\
\text { Apparatus". Article } 13 \text { of the law establishes guarantees for the legal and social protection of } \\
\text { employees of the state apparatus, including protection of the employee himself and his family } \\
\text { from violence, threats, and abuse connected performance of official duties. } \\
\text { According to the general principles of legislation (the Civil Code and Code of Civil } \\
\text { Proceedings), interested persons may demand compensation for losses suffered by wrongful } \\
\text { acts of a state body. Other kinds of punishment connected with professional activity may be } \\
\text { imposed only when National Bank employees commit unlawful acts. }\end{array}$ \\
\hline Assessment & Non-compliant. \\
\hline Comments & $\begin{array}{l}\text { The assessment is based on the deficiency, that there is no explicit provision in the laws of } \\
\text { Belarus, which provide legal protection to the supervisory authority and its staff against } \\
\text { lawsuits for actions taken while discharging their duties in good faith. The supervisory agency } \\
\text { and its staff are not protected adequately against the costs of defending their actions while } \\
\text { discharging their functions. }\end{array}$ \\
\hline Principle 1(6) & $\begin{array}{l}\text { Arrangements for sharing information between supervisors and protecting the confidentiality } \\
\text { of such information should be in place. }\end{array}$ \\
\hline Description & the cooperation and information sharing between the NBRB, the \\
\hline
\end{tabular}




\begin{tabular}{|c|c|}
\hline & 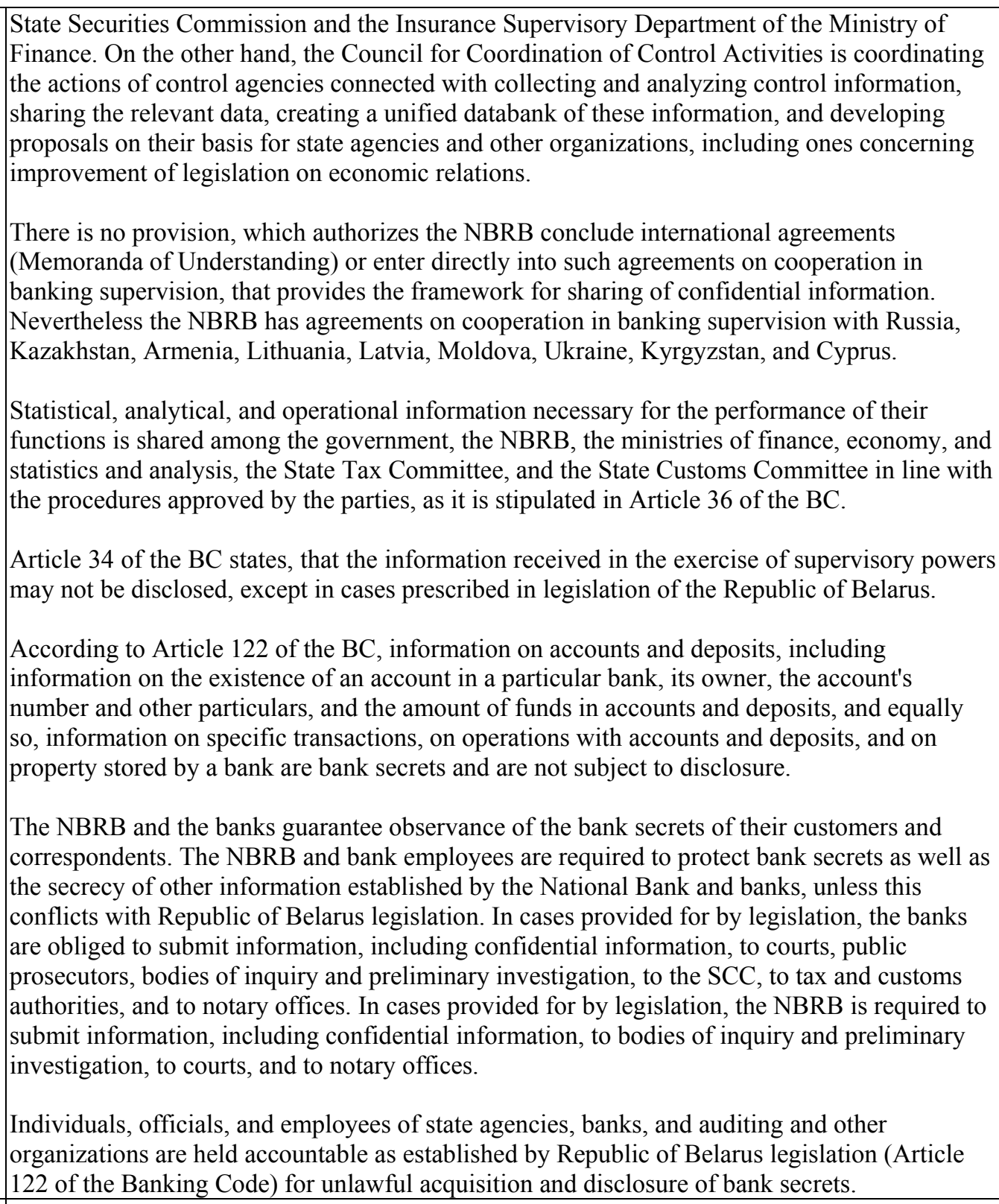 \\
\hline & Materially non-compliant. \\
\hline Comments & $\begin{array}{l}\text { The assessment reflects the deficiencies in two areas: the cooperation with the State Securities } \\
\text { Commission and Insurance Supervisory Department of the Ministry of Finance is not } \\
\text { formalized and the meetings and information exchange between the two authorities are not } \\
\text { regular. The procedure for sharing information among agencies supervising different segments } \\
\text { of the financial market has not been elaborated yet. The cooperation and information sharing } \\
\text { with the foreign counterparts is sporadic, except with the central bank of the Russian } \\
\text { Federation. There is no MoU with the Austrian banking supervisory authority (Austrian FMA), } \\
\text { while one of the largest banks is subsidiary of an Austrian bank. } \\
\text { In the opinion of the assessor, the main obstacle in concluding MoUs is the lack of protection } \\
\text { of confidential information. Even the definition of confidential information is missing from the } \\
\text { legislation, however the NBRB is prohibited from disclosing information received in the }\end{array}$ \\
\hline
\end{tabular}




\begin{tabular}{|c|c|}
\hline & $\begin{array}{l}\text { exercise of supervisory powers, except in cases prescribed in legislation of the Republic of } \\
\text { Belarus. } \\
\text { The NBRB is not able to deny a request for confidential information from the members of the } \\
\text { Council of Coordination. The law does not specify precisely what information the state } \\
\text { agencies and organizations constituting the Council for Coordination of Control Activities may } \\
\text { share without violating their own requirements on protection of their official information. To } \\
\text { sort out these relations between agencies with control function, the Belarusian authorities need } \\
\text { to develop and execute interagency agreements on the sharing of control information, and } \\
\text { confirm by statute the procedure for sharing information within the framework of the Council } \\
\text { for Coordination of Control Activities. } \\
\text { The guarantees for keeping the information provided for supervisory purposes should be } \\
\text { strengthened. }\end{array}$ \\
\hline $\mathbf{P}$ & $\begin{array}{l}\text { Permissible Activities } \\
\text { The permissible activities of institutions that are licensed and subject to supervision as banks } \\
\text { must be clearly defined, and the use of the word "bank" in names should be controlled as far } \\
\text { as possible. }\end{array}$ \\
\hline Des & 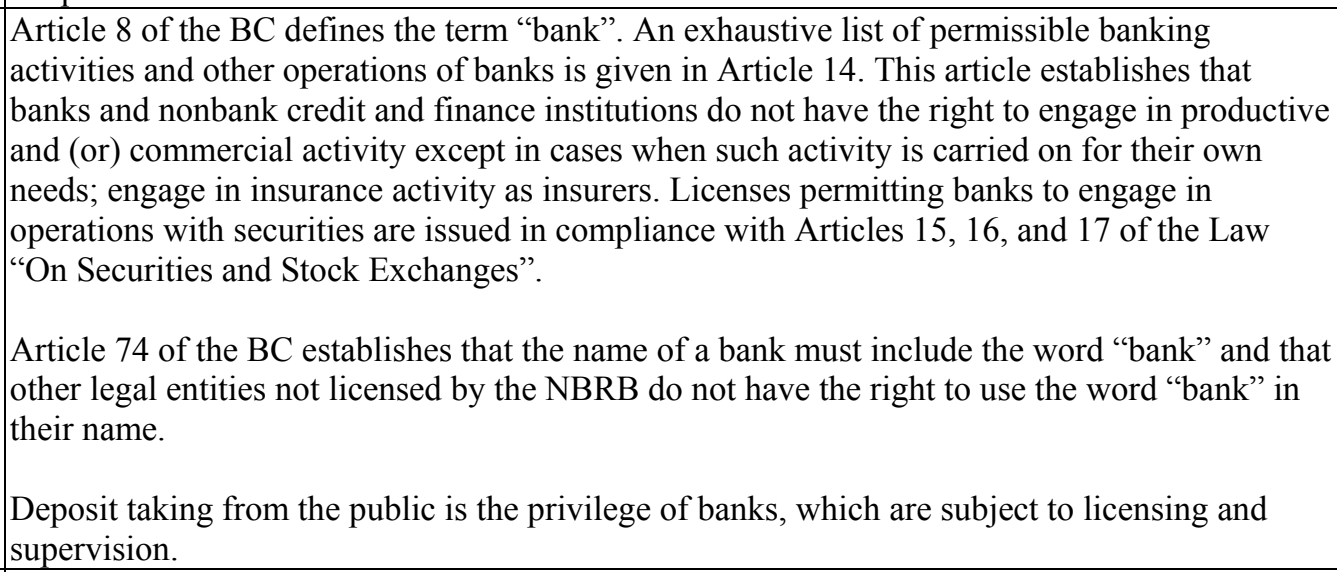 \\
\hline & \\
\hline Com & $\begin{array}{l}\text { The legislation meets all essential criteria. However, as certain activities may be similar or } \\
\text { apparently coincide with banking activity, the list of essential attributes constituting a certain } \\
\text { banking activity is advisable. Certain documents were issued by the NBRB on that issue. The } \\
\text { NBRB has to be authorized to determine the content of banking activities and in dubious cases } \\
\text { to justify the activity in question. }\end{array}$ \\
\hline Prin & $\begin{array}{l}\text { Licensing Criteria } \\
\text { The licensing authority must have the right to set criteria and reject applications for } \\
\text { establishments that do not meet the standards set. The licensing process, at a minimum, } \\
\text { should consist of an assessment of the banking organization's ownership structure, directors } \\
\text { and senior management, its operating plan and internal controls, and its projected financial } \\
\text { condition, including its capital base; where the proposed owner or parent organization is a } \\
\text { foreign bank, the prior consent of its home country supervisor should be obtained. }\end{array}$ \\
\hline D & $\begin{array}{l}\text { To obtain different types of licenses (general, internal, master, individual licenses, licenses for } \\
\text { depositing savings of population, and licenses for transactions involving precious metals and } \\
\text { stones) a bank must meet a number of requirements set by Chapter } 2 \text { of the Instructions on the } \\
\text { Procedure of State Registration and Licensing of Banks and Nonbank Credit and Finance } \\
\text { Institutions, approved by Republic of Belarus National Bank Supervisory Board Resolution } \\
\text { No. 175, June 28, 2001. (Instructions No.175) } \\
\text { The requirements imposed on a bank carrying out banking activities are the same as those }\end{array}$ \\
\hline
\end{tabular}


imposed on at the time when the license was issued.

The NBRB has the right to refuse state registration and to grant a license on grounds set forth in Article 82 and in the seventh part of Article 90 of the BC, and in item 30 of the Instruction No. 175.

Articles 81,82 , and 124 of the $\mathrm{BC}$ confer the right to request information about founders, to assess their financial condition, and to exercise control over the acquisition of significant interests in a bank's authorized capital.

In compliance with Article 112 of the BC, the NBRB sets the minimum amount of authorized capital for a new (reorganized) bank in accordance with Article 75 of the BC, the capital is established according to the Rules on Regulating Activities of Banks and Nonbank Credit and Finance Institutions, approved by Republic of Belarus National Bank Supervisory Board Resolution No. 173, June 28, 2001 (Rules No.173), for a new (reorganized) bank at an amount equivalent to $€ 5.0$ million, for an operating bank at an amount equivalent to $€ 5.0$ million, and for an operating bank licensed to attract resources of individuals for deposit at an amount equivalent to $€ 10.0$ million. The minimum capital requirement is only $€ 500.000$ for those banks which are registered and licensed as Free Trade Zone banks.

Based on Article 81 of the BC, the NBRB evaluates the professional suitability of directors of executive bodies and the chief accountant before making the decision on state registration. The procedure for evaluating professional suitability is established by the Regulation on Evaluation of Professional Fitness of Directors of Executive Bodies and Chief Accountants of Banks and Nonbank Credit and Finance Institutions, No. 105, April 28, 2001. Pursuant to Articles 80, 86, and 123 of the $\mathrm{BC}$, the $\mathrm{NBRB}$ imposes the following qualification requirements on directors of executive bodies of a bank and on directors of branches (offices): an education in economics or law, and work experience of not less than three years in the supervision of a bank department or other subdivision, confirmed by a copy of a diploma and an extract from a work record, and absence of non-clarified and unremitted charges; in the case of accountants of banks and branches (offices) a higher education in economics and a time of service of not less than three years as a bank accountant, confirmed by a copy of a diploma and an extract from a work record, and absence of non-clarified and unremitted charges.

In keeping with Article 80 of the $\mathrm{BC}$, a business plan containing a three-year a forecast of a bank's activities (calculated figures for planned income, expenditures, and profit) is submitted to the NBRB for state registration and licensing.

Article 73 of the BC specifies the requirements of the NBRB on the Articles of Association (charter) of a bank or a nonbank credit and finance institution containing the following information: the legal organizational form, legal address, list of banking operations and activities, the amount of authorized capital, and the management and internal control bodies.

According to Article 89 of the BC, state registration of a bank with foreign investments requires submission of written permission from the appropriate authority of the foreign investor's home country to participate in the authorized capital of a new bank in the Republic of Belarus, but only if the permission of the home country's authority is required by the home country's legislation. This requirement is also included in the MoUs on cooperation in banking supervision concluded by the NBRB with the central banks of other states.

If the information on the basis of which a bank has been registered and the banking license has been issued is found to be inaccurate, pursuant to Article 97 of the BCC the NBRB has the right to revoke the banking license.

Assessment Materially non-compliant. 


\begin{tabular}{|c|c|}
\hline Comments & $\begin{array}{l}\text { The law does not clarify that the proposed managerial structures of the bank will not hinder } \\
\text { effective banking supervision. The provisions of Article } 96 \text { of the BC on the reasons for denial } \\
\text { a banking license do not provide basis for this. } \\
\text { The Materially non-compliant assessment is based also on the fact, that the legislation does not } \\
\text { grant the NBRB the right explicitly to conduct a full analysis of a bank's ownership structure, } \\
\text { or to reveal the real owners of a bank and assess their potential influence on the bank's } \\
\text { activities, nor does it provide a definition of banking groups and bank holding companies or } \\
\text { grant the NBRB the right to supervise such entities, and assess their structure and their } \\
\text { influence on a bank's activities. The transparency of ownership is not assured. It is necessary to } \\
\text { find the owners beyond the first level and identify the ultimate owners, the criterion will be } \\
\text { met only after the incorporation of a regulation on this issue. The NBRB has no adequate } \\
\text { measures to verify the origin of the initial capital. The provision to call for financial statements } \\
\text { (Article } 80 \text { of the BC) was introduced by the BC, consequently the owners of the banks } \\
\text { established before } 2001 \text { were not verified thoroughly. It is recommended that the BSD remedy } \\
\text { this situation through an aggressive onsite examination process. } \\
\text { No definition is provided of the business reputation of a bank's founders and of candidates for } \\
\text { executive positions, in connection with which the assessment on fitness and properness is } \\
\text { limited mainly to the professional qualities of candidates for executive positions and absence } \\
\text { of a criminal record. Clear requirements on the business plans of new banks and the criteria of } \\
\text { their assessment by the NBRB on the basis of which a bank may be refused registration and } \\
\text { issuance of a license have not been established. }\end{array}$ \\
\hline Pri & $\begin{array}{l}\text { Ownership } \\
\text { Banking supervisors must have the authority to review and reject any proposals to transfer } \\
\text { significant ownership or controlling interests in existing banks to other parties. }\end{array}$ \\
\hline & $\begin{array}{l}\text { Article } 124 \text { of the BCC establishes that the permission of the NBRB is necessary for the } \\
\text { acquisition of more than } 10 \text { percent of the shares of a bank's authorized capital as a result of } \\
\text { one or more transactions executed by a single legal entity or natural person, or by a group of } \\
\text { legal entities and/or natural persons bound by an agreement, or by a group of legal entities that } \\
\text { are subordinated to or dependent upon another legal entity, and that NBRB receives } \\
\text { notification of the acquisition of more than } 5 \text { percent of the shares of a bank's authorized } \\
\text { capital. The particulars of the granting prior permission for the acquisition of more than } 10 \\
\text { percent of shares are set forth in item } 61 \text { of the Instructions No. } 175 \text {. } \\
\text { The NBRB has a right to refuse consent for the purchase of more than } 10 \text { percent of a bank's } \\
\text { shares when the court has shown the acquirer of the shares as insolvent or as not meeting } \\
\text { requirements imposed on a bank's founders by the BC. } \\
\text { In accordance with Article } 84 \text { of the BC, changes and additions to the founding documents } \\
\text { (Articles of Association) of a bank have to be submitted to the NBRB for the purpose of } \\
\text { registration. The registration may be denied if on the date of application for state registration at } \\
\text { least one of its shareholders: } \\
\text { - is a shareholder of three or more legal entities other than open incorporated societies } \\
\text { and commercial organizations engaged, for the most part, in production activities; } \\
\text { - is in arrears of wages and/or payments to the budget or purpose-oriented state } \\
\text { budgetary and off-budgetary funds and is a promoter of legal entities that are in arrears } \\
\text { of wages and/or payments to the budget or purpose-oriented public budgetary and off- } \\
\text { budgetary funds; } \\
\text { - is a public association pursuing political aims; } \\
\text { - an individual entrepreneur or shareholder of a legal entity with respect to which a } \\
\text { decision on cessation of activity (liquidation) has been taken but the cessation } \\
\text { (liquidation) process is not yet complete; }\end{array}$ \\
\hline
\end{tabular}




\begin{tabular}{|c|c|}
\hline & $\begin{array}{l}\text { - was an individual entrepreneur who terminated his activity or a shareholder of a legal } \\
\text { entity liquidated on representation of the authorized body if less than three years have } \\
\text { passed since the date of their elimination from the Unified State Register of Legal } \\
\text { Persons and Individual Entrepreneurs; or } \\
\text { - whose right to carry out business has been restricted by court decision. } \\
\text { The founding document and its modifications should include the names of stockholders as an } \\
\text { annex. If there is a change in the amount of the authorized fund, the list of the stockholders of } \\
\text { the bank has to be adjusted to reflect the amounts of their contributions, the total amount of the } \\
\text { funds, and the share of the stockholders in the bank's authorized capital. }\end{array}$ \\
\hline Assessment & Materially non-compliant. \\
\hline Comments & $\begin{array}{l}\text { The assessment reflects that, the legislation does not contain a clear definition of "significant" } \\
\text { ownership. The NBRB derives that from the provision of the BC, according to which } \\
\text { acquisition of more than } 10 \% \text { requires the permission of NBRB. In the practice the NBRB } \\
\text { gives permission to each } 10 \% \text { tranche }(10 \%, 20 \% \text {, etc.), although these thresholds are not } \\
\text { mentioned in the BC. As far as the transfer of ownership to non-residents is concerned, the } \\
\text { permission of NBRB is necessary for all transactions, notwithstanding the amount of shares, } \\
\text { while every resident can buy up to } 9.99 \% \text { without permission. Taking into account, that the } \\
\text { NBRB is not able to detect if the buyers are acting in concert, the } 10 \% \text { threshold can be easily } \\
\text { circumvented. For purchases of shares over } 5 \% \text { (between } 5 \% \text { and } 10 \%) \text { the bank is obliged to } \\
\text { inform the NBRB that the transaction took place } \\
\text { The Materially non-compliant rating is also based on the fact, that controlling interest is not } \\
\text { regulated by the BC. According to the Civil Code } 50 \%+1 \text { of the voting shares is a controlling } \\
\text { interest. The Civil Code empowers the shareholders to establish controlling blocks in the } \\
\text { charter of the company. Thus the General Assembly of the bank may decide the level, above } \\
50 \% \text {, that is needed for taking certain decisions. }\end{array}$ \\
\hline Principle 5. & $\begin{array}{l}\text { Investment Criteria } \\
\text { Banking supervisors must have the authority to establish criteria for reviewing major } \\
\text { acquisitions or investments by a bank and ensuring that corporate affiliations or structures do } \\
\text { not expose the bank to undue risks or hinder effective supervision. }\end{array}$ \\
\hline Description & $\begin{array}{l}\text { Article } 112 \text { of the BC specifies that the NBRB establishes standard for bank participation in } \\
\text { investment. Article } 118 \text { of the BC lays down that the NBRB establishes the following } \\
\text { standards for banks for the purpose of controlling the investments of banks with their own } \\
\text { funds: } \\
\text { - } \quad \text { the standard on a bank's contribution of its equity capital to the authorized capital of a } \\
\text { single legal entity; } \\
\text { - } \quad \text { the standard on maximum participation in the authorized capital of all legal entities } \\
\text { taken together (aggregated). } \\
\text { The standard on a bank's contribution of its equity capital to the authorized capital of a single } \\
\text { legal entity and the authorized capital of all legal entities taken together is determined by the } \\
\text { NBRB in the form of a maximum percentage of the bank's equity. The Rules No. } 173 \text {. } \\
\text { establishes the followings: } \\
\text { - The standard of participation in the authorized fund of one legal person should not } \\
\text { exceed 5\% of own funds (capital) of a bank (nonbank credit and financial institution). } \\
\text { - The standard of maximum participation in authorized funds of all legal persons in the } \\
\text { aggregate may not exceed } 25 \% \text { of own funds of a bank (nonbank credit and financial } \\
\text { institution). }\end{array}$ \\
\hline & $\begin{array}{l}\text { Banks and nonbank credit and financial institutions must notify the NBRB of any investment } \\
\text { of own funds in authorized funds of legal persons, irrespective of the extent of participation } \\
\text { thereof. Where investments exceed } 10 \% \text { of the authorized fund of another legal person, banks } \\
\text { (nonbank credit and financial institutions) must seek authorization from the NBRB. }\end{array}$ \\
\hline
\end{tabular}




\begin{tabular}{|c|c|}
\hline & $\begin{array}{l}\text { A bank or a nonbank credit and financial institution may participate in the authorized fund of } \\
\text { another bank or nonbank credit and financial institution only with the consent of the National } \\
\text { Bank. } \\
\text { When a bank calculates its capital adequacy ratio, it decreases its equity capital by the amount } \\
\text { of its investments into subsidiary banks, nonbank credit and finance institutions, and other } \\
\text { subsidiary legal entities, as well as its investments amounting to } 20 \text { percent or more of an } \\
\text { issuer's authorized capital. } \\
\text { The procedure for obtaining permission and the criteria for granting it are specified in item } 83 \\
\text { of the Rules No. 173. In particular, } \\
\quad-\quad \text { economic reasoning for the need to invest funds; } \\
\quad-\quad \text { confirmation of available investment sources; } \\
\quad-\quad \text { compliance with the capital adequacy standard and how the funds being withdrawn for } \\
\quad \text { investment affect it } \\
\text { are reviewed by the NBRB when determining the bank's possibilities for making investments. } \\
\text { Shares acquired for trading purposes are not taken into account when calculating the amount of } \\
\text { a bank's participation in investments. } \\
\text { The National Bank is also required to control the influence of major acquisitions or capital } \\
\text { investments on the financial condition of banks which underwent financial recovery in } \\
\text { accordance with the Law "On Economic Insolvency (Bankruptcy)." }\end{array}$ \\
\hline Asse & Materially non-compliant. \\
\hline Comn & $\begin{array}{l}\text { The assessment is based that the laws and regulations clearly define the types and amounts of } \\
\text { acquisitions and investments which need supervisory approval and which need to be reported } \\
\text { to the NBRB. Rule No.173 provides general criteria by which the individual cases can be } \\
\text { judged. In practice however, supervision of the investments of banks in the authorized capital } \\
\text { of other legal entities is for the most part formal in nature. The NBRB does not conduct any } \\
\text { additional analysis of the adequacy of a bank's organizational resources of the management of } \\
\text { acquired interests , nor does it establish the criteria for determining the influence legal entities, } \\
\text { into the authorized capital of which a bank has made major investment, may have on the } \\
\text { bank's activities. Hence, it is questionable if the risks of the investment can assessed and } \\
\text { whether the effective supervision can be carried out. A "materially non-compliant assessment" } \\
\text { is given when the shortcoming is sufficient to raise doubts about the authority's ability to } \\
\text { achieve compliance, but substantive progress had been made. The amendment of the BC is } \\
\text { desirable in order to establish the NBRB's power to supervise banks on a consolidated basis, } \\
\text { with consideration for subsidiary and dependent legal entities constituting a banking group } \\
\text { (holding company). }\end{array}$ \\
\hline Pri & $\begin{array}{l}\text { Capital Adequacy } \\
\text { Banking supervisors must set minimum capital adequacy requirements for banks that reflect } \\
\text { the risks that the bank undertakes, and must define the components of capital, bearing in } \\
\text { mind its ability to absorb losses. For internationally active banks, these requirements must } \\
\text { not be less than those established in the Basel Capital Accord. }\end{array}$ \\
\hline Descr & $\begin{array}{l}\text { Article } 112 \text { of the BC, the NBRB establishes economic standards, including capital adequacy } \\
\text { standards, which are established - pursuant to Article } 115 \text { of the BC - as the minimum ratio of } \\
\text { equity (own fund) to risk-weighted assets on the balance sheet, as well as off-balance sheet } \\
\text { items assessed as to their risk level. } \\
\text { Rules No. } 173 \text { establish the standards on the adequacy of equity capital and on the adequacy of } \\
\text { core capital as the minimum percent ratio of the amount of a bank's equity capital (own funds) } \\
\text { to the total amount of risk-weighted assets and off-balance sheet liabilities, less created } \\
\text { reserves. }\end{array}$ \\
\hline
\end{tabular}


Capital adequacy requirements are established for all banks in the country, including internationally active banks, and currently they exceed the level of the Basel recommendations. The procedure for calculating equity capital (own funds) is established by Rule No.173, and it distinguishes two levels of capital: "core capital" and "supplementary capital". The minimum of the capital adequacy ratio is established at 14 percent for the first two years of a bank's activity, and 10 percent thereafter. The minimum of the adequacy ratio of core capital is established at 7 percent for the first two years of a bank's activity, and 5 percent thereafter. (These will be reduced to 12 percent and 8 percent for the capital and to 6 percent or 4 percent for the core capital from1st of January, 2005.)

The components of the bank's capital are in line with the recommendations of the Basel Committee. The procedures for risk-weighting assets and calculating the credit risk of offbalance sheet liabilities and forward transactions are also established by the Rules. According to Article 113 of the $\mathrm{BC}$, the components of bank equity capital (own funds) are determined based on their ability to absorb losses.

Pursuant to the Regulations on Corrective Actions Taken by the Republic of Belarus National Bank Against Banks and Nonbank Credit and Finance Institutions, approved by Republic of Belarus National Bank Board of Supervisors Resolution No. 3, January 25, 2001 (Regulations No. 3), corrective actions can be taken if a bank is non-compliant with the standards on minimum equity capital, on adequacy of capital, and on adequacy of core capital. According to Article 181 of the Law on Bankruptcy, an absolute decrease in a bank's equity capital by more than 20 percent below the maximum of the most recent 12 months and a bank's violation of the capital adequacy standard are grounds for taking measures to prevent a bank's bankruptcy. According to Article 193 of the Law on Bankruptcy, an absolute decrease in a bank's equity capital by more than 30 percent of the maximum of the in most recent 12 months is a ground for the appointment of an interim administration by the NBRB, or for requiring a bank's reorganization (Article 208 of the Law on Bankruptcy).

Rule No.173 prescribes a monthly procedure for filing reports with the NBRB on the calculations for the amount of a bank's equity capital and for the indicators of the adequacy of core capital and equity capital.

The verification of capital adequacy ratios is part of the on-site examinations, including the assessment of an internal system for assessing capital adequacy, plans for safeguarding and increasing capital and maintaining its adequacy

The minimum absolute capital for banks are defined in the BC. (See CP 3).

Assessment Materially non-compliant.

\begin{tabular}{l|l} 
Comments & The assessment is based on the fact, that the required minimum capital adequacy ratio is higher
\end{tabular} than those established in the Basel Capital Accord, which reflects the economic situation of the country, however the market risks and other risks are not covered.

There is no explicit requirement in the legislation that banks have to consistently maintain a minimum capital adequacy ratio. This requirement can be drawn from the supervisory measures, which must be taken by the NBRB, if a bank's capital adequacy ratio falls below the prescribed threshold.

The capital ratio does not fully reflect the risk profiles of the banks, as there is no capital charge on market risks at the time of the assessment. In order to enable the banks to cover market risks, the ratios will be lowered and the tier 3 capital will be allowed, as of $1^{\text {st }}$ of January, 2005. Also it is recommended not to reduce the level of capital adequacy requirement to $8 \%$ as planned. The level should remain at $10 \%$. 


\begin{tabular}{|c|c|}
\hline & Capital adequacy ratios are not calculated and applied on a consolidated bank basis. \\
\hline Principle 7. & $\begin{array}{l}\text { Credit Policies } \\
\text { An essential part of any supervisory system is the independent evaluation of a bank's policies, } \\
\text { practices, and procedures related to the granting of loans and making of investments and the } \\
\text { ongoing management of the loan and investment portfolios. }\end{array}$ \\
\hline Description & $\begin{array}{l}\text { The Instructions on Procedure for Granting of Monetary Resources in the Form of Loan and } \\
\text { their Repayment, approved by Republic of Belarus National Bank Supervisory Board } \\
\text { Resolution No. 226, December 30, } 2003 \text { (Instructions No. 226) prescribes, that an authorized } \\
\text { body of a bank shall approve internal rules which stipulate: } \\
\text { - } \text { mandatory conditions and procedure for granting (placing) money resources and their } \\
\text { repayment, } \\
\text { - } \text { procedure for making decisions on granting (placing) money resources, } \\
\text { - } \text { procedure for identifying (verifying) the legal capability and solvency } \\
\text { (creditworthiness) of the borrower, } \\
\text { - procedure for discovering the value of the property accepted as collateral to secure } \\
\text { - } \text { execution of liabilities } \\
\text { types and ways of lending which does not require monitoring earmarked use of the } \\
\text { - loan, } \\
\text { - } \text { procedure for control over earmarked use of granted loans, }\end{array}$ \\
\hline
\end{tabular}

As indicated above, policies, practices, and procedures for granting and extension of credits shall be in place and their approval, implementation, and periodic review by the authorized administrative bodies of a bank is obligatory. Also, a bank is required to develop internal rules specifying the conditions and procedures for extending credits, and the powers of branches and other structural subdivisions of the banks and of its officers to carry out credit operations and control timely repayment of extended credit. The procedure for issuing credits established by Instructions No. 226 also provides, that credit agreements with customers are signed by bank or branch executives in keeping with the powers granted to such a bank employee in accordance with the regulations. The final decision on issuing credit is to be made by a bank's authorized body in accordance with its internal rules, which were prepared with consideration for the legislation of the Republic of Belarus. Internal rules of a bank regulating extension of resources in the form of credit, set forth not only the procedures for reviewing credit applications but also the procedures for monitoring the loan debt and the financial condition of the credit recipient in the course of servicing such credit. The compliance with the internal rules is controlled by the bank's administrative body having the appropriate powers.

The Rules No. 173 provides that a bank's authorized bodies must prepare and approve an internal regulation on control of the performance of risky operations that regulates the relevant procedures of control, powers, interaction with branches and other measures ensuring reasonable management and limitation of risks, including in credit operations. The internal rules of banks on risk control limit the powers of branches to accept credit risks, and establish the main parameters of credit operations. A bank's internal documents pertaining to limits on credit risks also set forth the approaches to extending credits to interconnected customers and to persons connected with the bank (insiders, founders, bank employees), and other approaches pursuant to Republic of Belarus legislation ensuring adequate control of credit risk. The main approaches to organizing a bank's system of internal control of risks, including credit risk, are specified in NBRB Letter No. 23-09/135, March 31, 1999 "On Recommendations on Organizing the System of Bank Internal Control of Banking Risks.” The procedure of internal control of credit risk includes, among other things, collection and analysis of information on the financial condition of credit recipients, their reputation, appraisal of collateral, and other criteria ensuring that the bank possesses necessary details regarding the condition of the credit and investment portfolios. 


\begin{tabular}{|c|c|}
\hline & 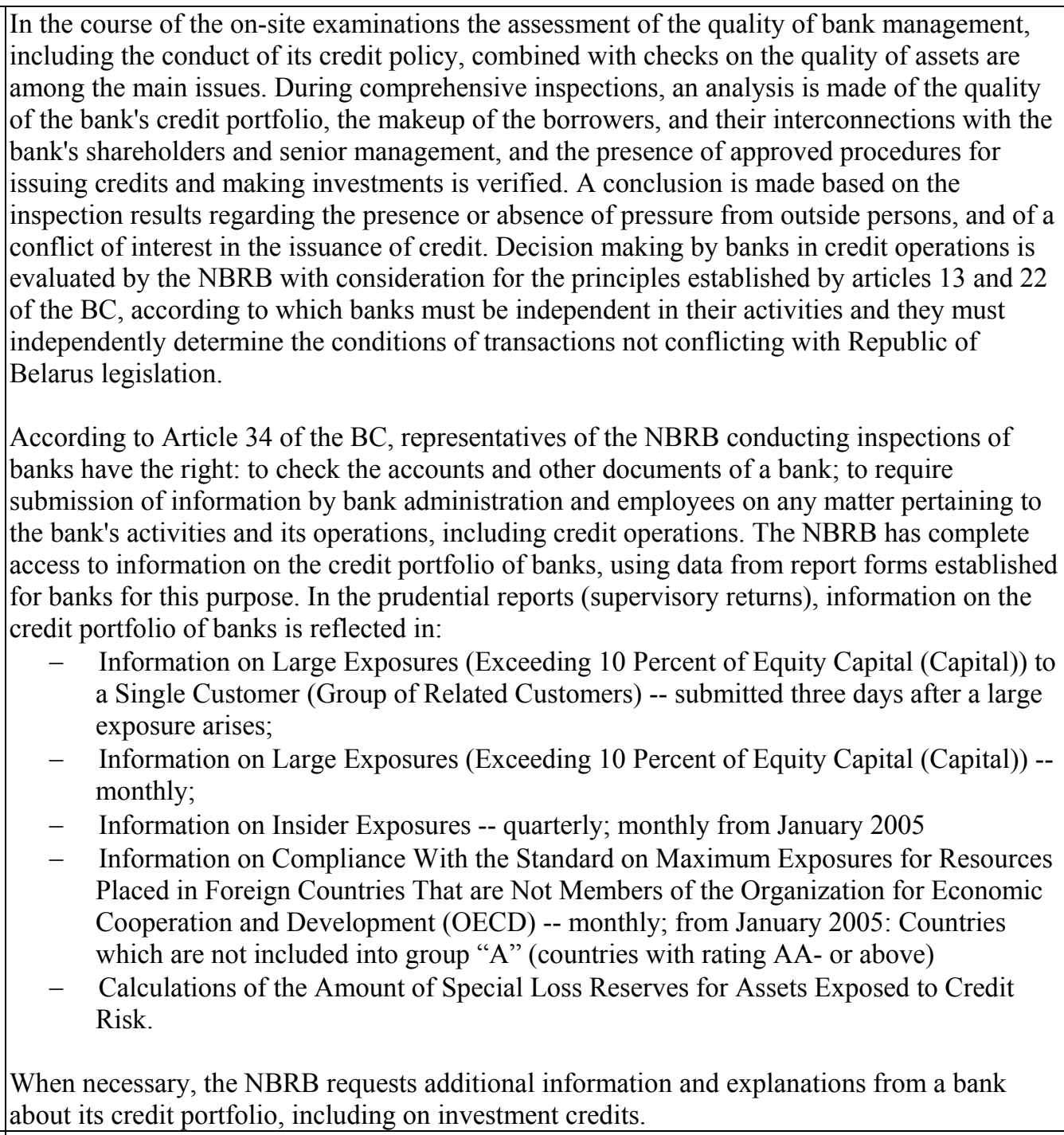 \\
\hline Assessment & Largely compliant. \\
\hline Comments & $\begin{array}{l}\text { In practice, the banks are not free from inappropriate pressure from outside parties. That is, the } \\
\text { banks are not independent in their decisions to place credits in the cases when regulations } \\
\text { adopted by the President of the Republic and by government of the Republic of Belarus } \\
\text { actually require banks to allocate resources for lending to various programs with a social } \\
\text { orientation. Experience has shown that these credits are often extended to insolvent } \\
\text { enterprises, which ultimately leads to worsening of the bank's financial condition. Supervisory } \\
\text { forbearance is also perceivable. As placement of such credits is often accompanied by the } \\
\text { bank's violation of one or more economic standards, in these cases the decision making bodies } \\
\text { of the NBRB decides to relieve the bank from accountability for these violations in the future } \\
\text { (up to the end of the credit term). It should be noted that bank branches located in the regions } \\
\text { (oblasts) are under the influence of local authorities, and often the bank headquarters are not } \\
\text { informed on a decision to extend credit. The practice of making any kind of exceptions for } \\
\text { banks carrying out certain operations by order of bodies of state needs to be eliminated from } \\
\text { banking supervision, and it must be insisted that banks be free from pressure in their banking } \\
\text { activities. } \\
\text { Considering the abovementioned practices and repeated re-capitalization by the state of some }\end{array}$ \\
\hline
\end{tabular}




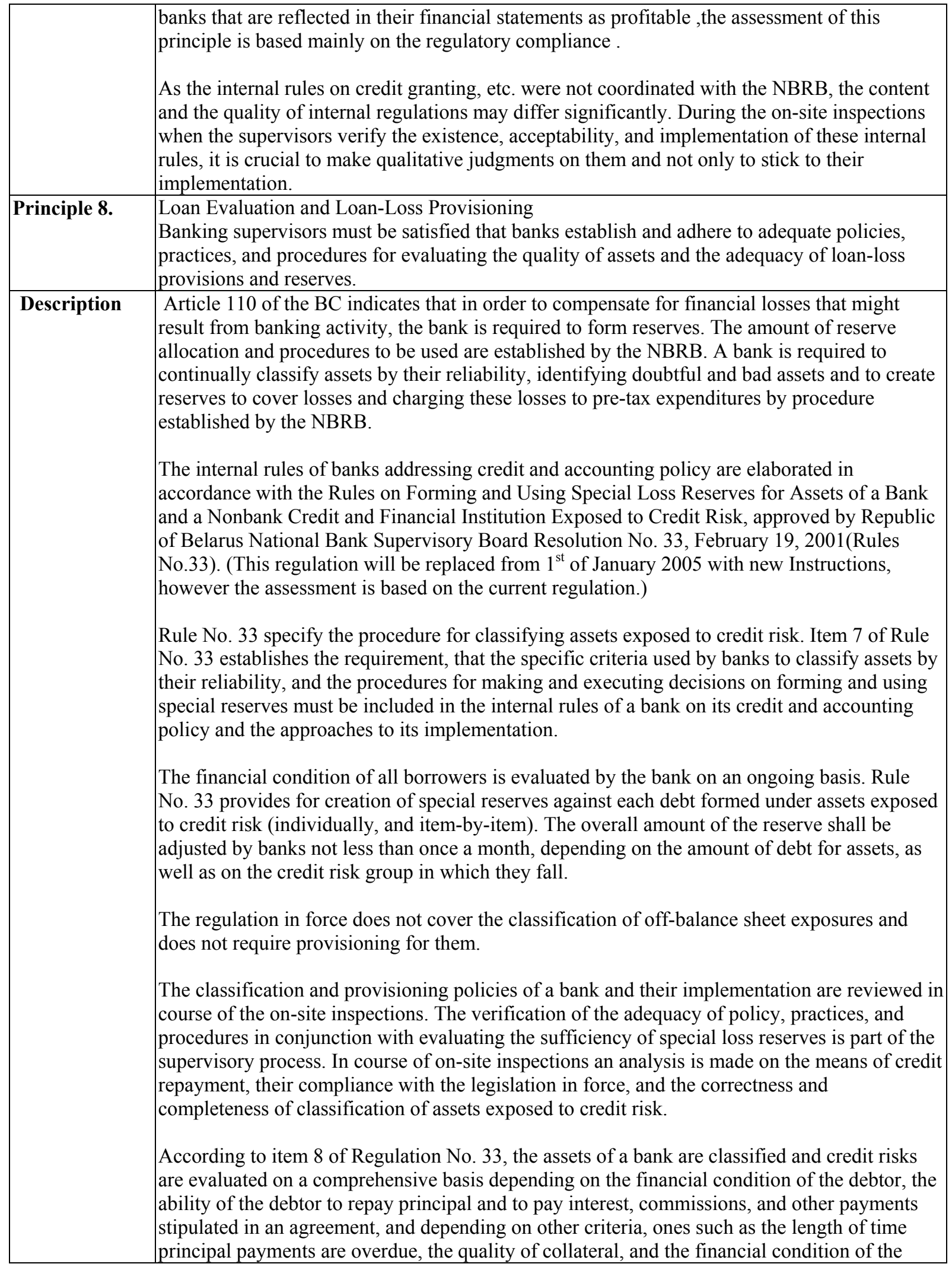




\begin{tabular}{|c|c|}
\hline & 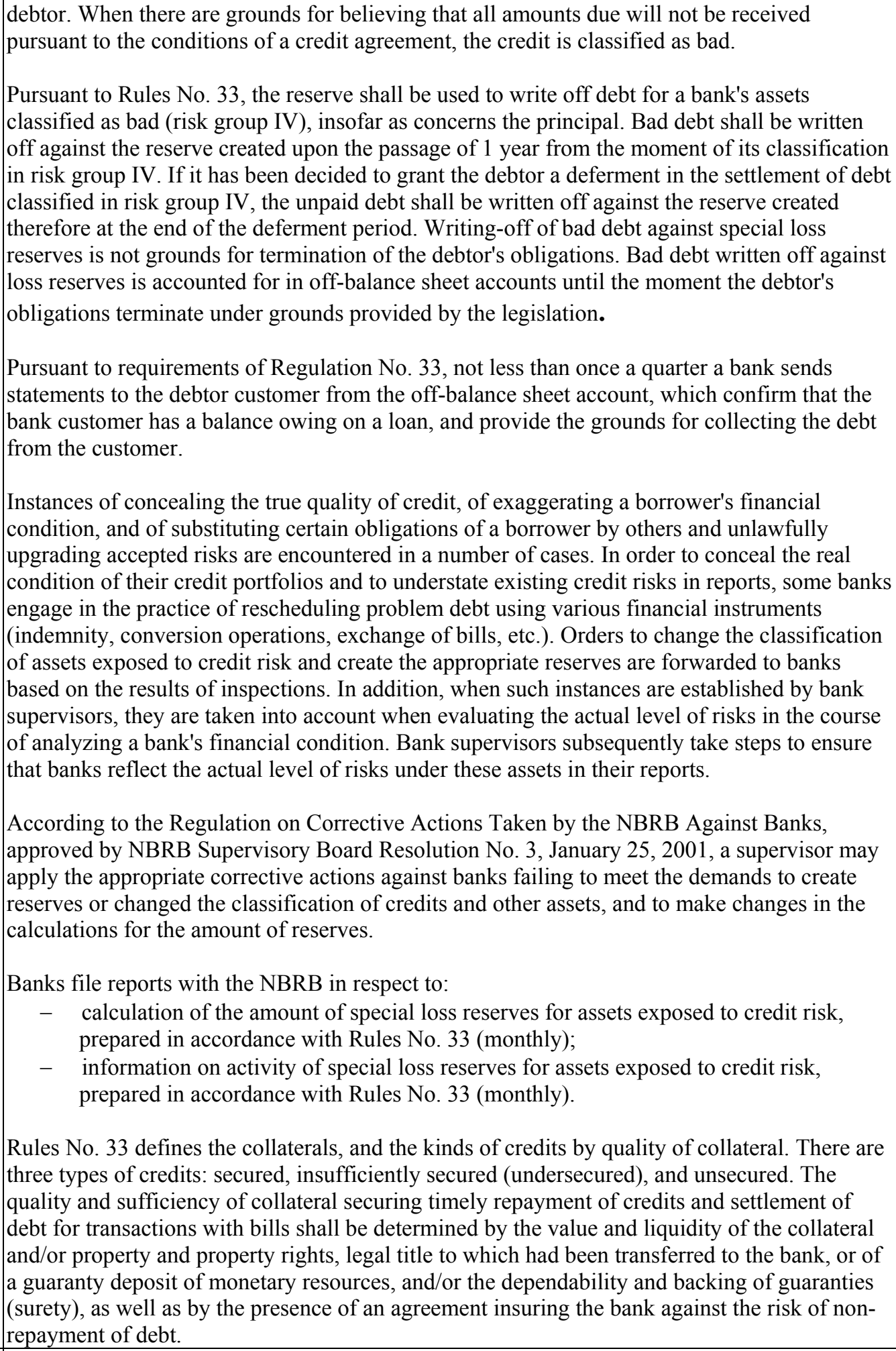 \\
\hline & Largely com \\
\hline Comments & ation to assess that banks \\
\hline
\end{tabular}




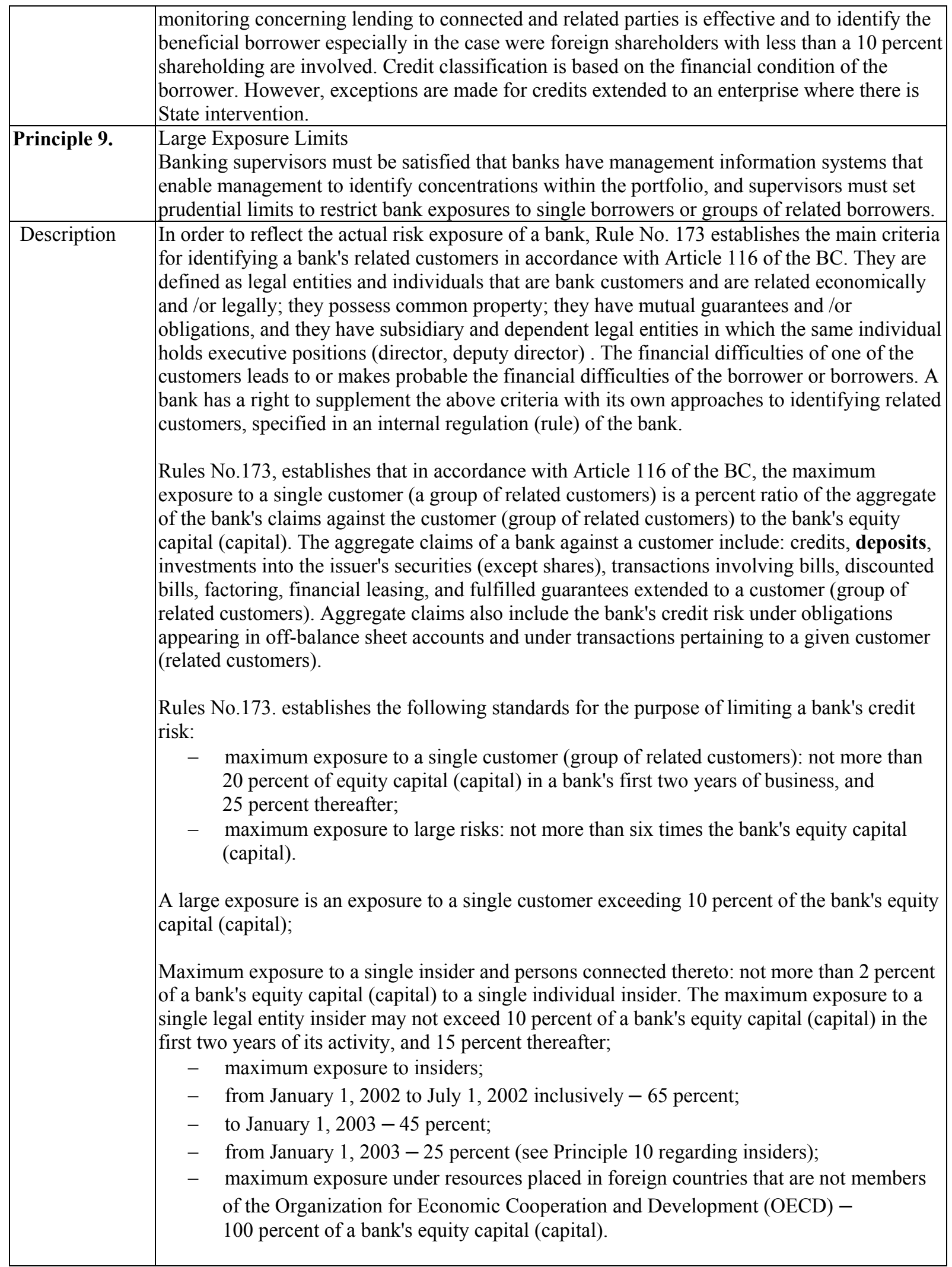




\begin{tabular}{|c|c|}
\hline & $\begin{array}{l}\text { The calculations for the standards above include the credit risk for off-balance sheet } \\
\text { instruments and forward transactions. } \\
\text { The Rules provide that a bank's authorized bodies are required to develop and approve internal } \\
\text { rules (regulation) addressing controls on performance of risky transactions governing the } \\
\text { particular control procedures, powers, interaction with branches (offices), and other measures } \\
\text { ensuring prudent risk management and limitation. A decision to place resources, including in } \\
\text { the form of credits, that creates large exposures is to be made obligatorily by a bank's } \\
\text { authorized administrative body. } \\
\text { The NBRB controls bank compliance with the above requirements and issues } \\
\text { recommendations on identifying large exposures within the framework of its supervisory } \\
\text { functions and by receiving monthly and current reports on large exposures and other reports on } \\
\text { fulfillment of the above standards, and in the course of inspections. Information on credit } \\
\text { investments is broken down by activities (industry, agriculture, forestry, construction, trade, } \\
\text { etc.), on forms of ownership (state, private, other), terms (long-term and short-term } \\
\text { investments), and on a regional cross section in the Republic of Belarus is forwarded monthly } \\
\text { by banks in compliance with requirements set forth in National Bank Letter No. 17-18/5998, } \\
\text { dated April 26, 2002. This information is set forth in its dynamics from the beginning of the } \\
\text { year (issued, repaid, the balance of debt at the end of the reporting month) broken down by } \\
\text { currencies (domestic, foreign), and it includes information both on standard and on problem } \\
\text { credits. In keeping with Instructions on Compiling Financial Report Forms Filed by Banks and } \\
\text { Nonbank Credit and Finance Institutions with the Republic of Belarus National Bank, in the } \\
\text { version approved by National Bank Supervisory Board Resolution No. 20, January } 31,2003 \text {, } \\
\text { banks are required to accumulate and systematize, on an ongoing basis, information on } \\
\text { concentration of assets, liabilities, and off-balance sheet items, broken down by economic } \\
\text { regions, industries of the economy, forms of ownership, and foreign capital participation. This } \\
\text { information is filed with the NBRB when so requested thereby. }\end{array}$ \\
\hline & Materially non-compliant. \\
\hline & $\begin{array}{l}\text { The NBRB has no discretionary power in the interpretation of "closely related group" on a } \\
\text { case-by-case basis. Furthermore, the legislation does not grant the NBRB the right to make an } \\
\text { independent evaluation of relations of a bank's customers between each other for the purposes } \\
\text { of revealing groups of related debtors, or to require a bank to make the relevant corrections in } \\
\text { its reports. } \\
\text { In most respects, the NBRB's systems for ensuring that banks do not have excessive large } \\
\text { exposures and maintain prudent systems for managing their large exposures are reasonably } \\
\text { adequate and well applied. However, it is applied to data that does not take into consideration } \\
\text { the lack of detailed information on the financial activities of a number of shareholders below } \\
\text { the } 10 \text { percent threshold. } \\
\text { There have been cases in which decision making bodies of the NBRB have adopted decisions } \\
\text { not to take corrective actions against a bank for violations of established requirements of } \\
\text { standards. These decisions are made in connection with the state importance or social } \\
\text { orientation of the measures to which credits are granted, and so on, and they pertain mainly to } \\
\text { the operations of systemically important banks supporting fulfillment of the requirements of } \\
\text { bodies of state administration. This practice should be eliminated in order to ensure the } \\
\text { consistent treatment in evaluating the financial condition and risks of a bank, and that equal } \\
\text { business conditions are provided for banks. The bodies of state administration should refrain } \\
\text { from exerting pressure on banks that could lead to worsening of their financial condition that } \\
\text { cannot be remedied. }\end{array}$ \\
\hline $\mathbf{P}$ & $\begin{array}{l}\text { Connected Lending } \\
\text { In order to prevent abuses arising from connected lending, banking supervisors must have in } \\
\text { place requirements that banks lend to related companies and individuals on an arm's-length }\end{array}$ \\
\hline
\end{tabular}




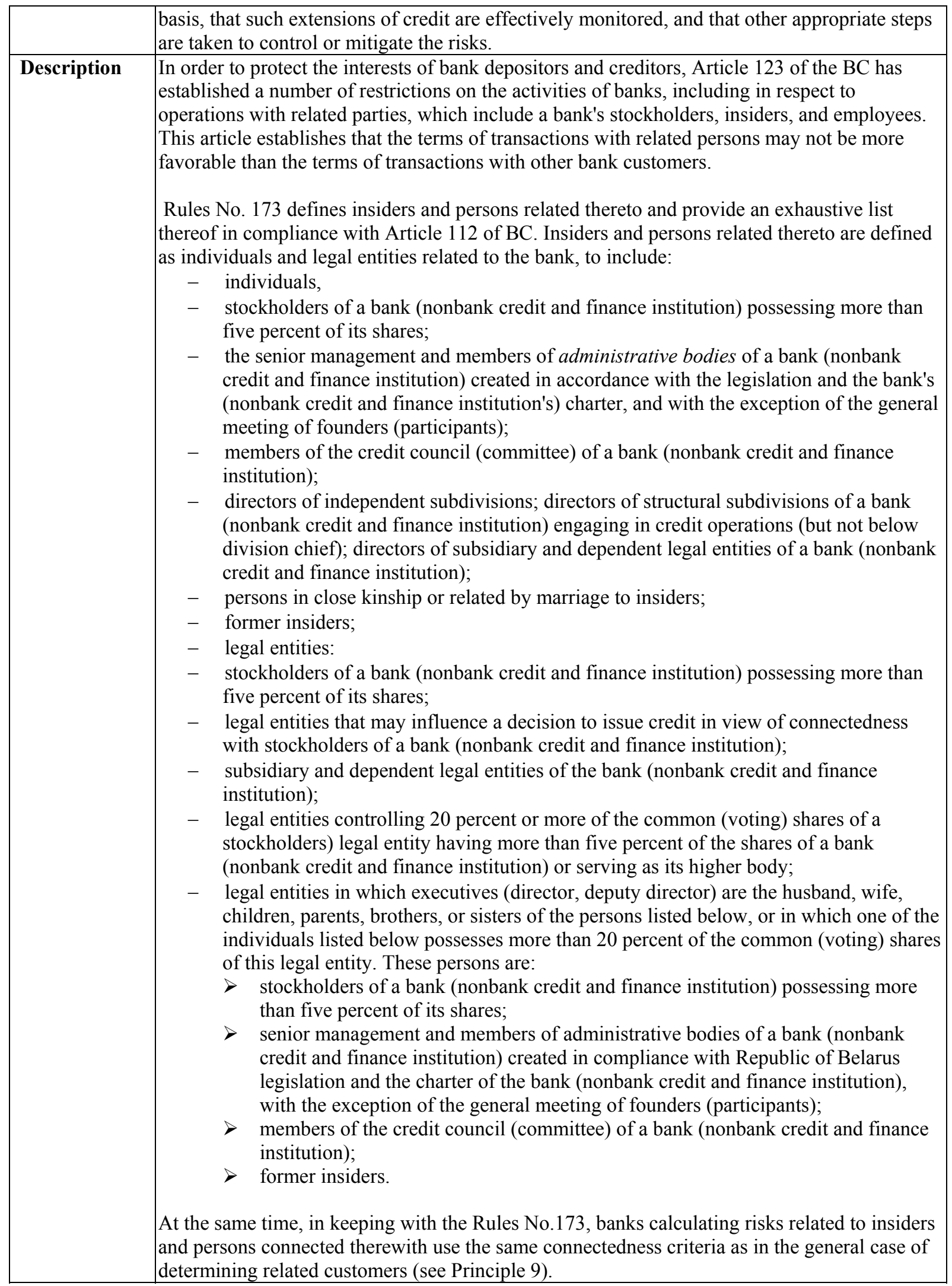


The Rules have established the following standards to permit supervision of bank operations with insiders:

- maximum exposure to a single insider and to persons connected therewith;

- maximum exposure to all insiders.

The maximum exposure to a single insider and to persons connected therewith (insider) is the percent ratio of the aggregate amount of claims, including the credit equivalent of the amount of off-balance sheet obligations in favor of a single insider, to a bank's equity capital (capital). Stricter requirements are imposed by the Rules No. 173. on the risks of banks in operations with insiders than on risks related to other customers.

- The maximum exposure to a single individual insider may not be more than two percent of a bank's equity capital (capital).

- The maximum exposure of a single legal entity insider may not exceed 10 percent of a bank's equity capital (capital) in the first two years of its activity, and 15 percent thereafter.

- The maximum exposure to all insiders is the percent ratio of the aggregate amount of all exposures to insiders (individuals and legal entities) to the equity capital (capital) of a bank, and it is set at 25 percent.

Rules No.173. provide that a bank is required to control compliance with maximum exposure to a single insider and to connected persons at the moment the resources are placed and on the first of the month following the reporting month, based on the amount of the bank's equity capital (capital) as of the last reporting date.

A decision to place resources with insiders that leads to the emergence of large exposures is to be made obligatorily by the authorized administrative body of a bank in accordance with internal rules on controls on risky operations elaborated by the bank.

The NBRB applies corrective actions foreseen for violation of standards on maximum exposure to a single customer (a group of related customers) against banks violating standards on exposure to a single insider and to persons connected therewith, and on maximum exposure to all insiders.

Information on the amount of all exposures to insiders is filed quarterly with the National Bank.

Exposures to insiders falling into the category of large exposures are included in reports on large exposures filed by banks quarterly, as well as within three days from the moment a large exposure arises.

Recommendations of the NBRB on organizing internal controls of a bank and current acts of banking legislation require a bank to monitor credit risk pertaining to parties related to the bank within the framework of general monitoring of credit risk.

On-site inspection of a bank's investments verify the absence of favoritism in determining the terms under which credits and other assets exposed to credit risk are granted to this group of customers is a constituent part of an inspection of a bank having the purpose of analyzing the quality of assets.

\begin{tabular}{|l|l|}
\hline Assessment & Largely compliant \\
\hline Comments & $\begin{array}{l}\text { The definition of "connected and related parties" is not specified in the law or in the } \\
\text { regulation. Starting January 2005 the regulation will be amended with respect to former } \\
\text { insiders: former insiders can be only natural persons and the term for being such a person has } \\
\text { been reduced from five years to one year. In other aspects the regulation will be stricter. }\end{array}$ \\
\hline
\end{tabular}




\begin{tabular}{|c|c|}
\hline & $\begin{array}{l}\text { However supervisors lack discretion to make judgments about the existence between the bank } \\
\text { and other parties. The legislation does not grant the NBRB the right to make an independent } \\
\text { evaluation of the relations of a bank's customers with the bank for the purposes of revealing } \\
\text { insiders that are not listed in the bank's reports, or to require a bank to make the relevant } \\
\text { corrections in its reports. } \\
\text { Regulations of the NBRB do not provide approaches allowing reduction of equity capital } \\
\text { (capital) when calculating capital adequacy by the amount by which maximum exposure to } \\
\text { insiders exceeds the established standards. This issue will be examined at the time changes are } \\
\text { made to the Rules. } \\
\text { The NBRB does not receive all the necessary information to assess that banks monitoring } \\
\text { concerning lending to connected and related parties is effective to identify the beneficial } \\
\text { borrower especially in the case were foreign shareholders with less than a } 10 \text { percent } \\
\text { shareholding are involved. }\end{array}$ \\
\hline Pri & $\begin{array}{l}\text { Banking supervisors must be satisfied that banks have adequate policies and procedures for } \\
\text { identifying, monitoring and controlling country risk and transfer risk in their international } \\
\text { lending and investment activities, and for maintaining appropriate reserves against such risks. }\end{array}$ \\
\hline$D e$ & $\begin{array}{l}\text { Article } 110 \text { of the BC requires a bank to timely identify, control and minimize the risks that } \\
\text { threaten its financial soundness. Also, banks are required to continually categorize assets as to } \\
\text { their reliability, identifying doubtful and bad assets and to establish reserves for potential } \\
\text { losses. In addition, the Article requires banks to establish internal controls adequate with the } \\
\text { nature and volume of banking operations being performed. } \\
\text { NBRB Instruction 92, dated June } 2004 \text { and to take effect on January 2005, on Economics } \\
\text { Standards for Banks and Nonbank Credit and Financial Organization requires that risk } \\
\text { assessment for the calculation of capital, liquidity adequacy, and the maximum amount of risk } \\
\text { be based on the rating of the counterpart of the banking operation. The instructions require that } \\
\text { when assessing the amount of risks of assets in foreign countries, a bank shall utilize an } \\
\text { approach based on the rating of the foreign country. } \\
\text { Moody's Investors Service, Fitch and Standard \& Poor's ratings of countries are utilized to } \\
\text { place countries in Groups A to E. Countries in Group A to are those that the three rating } \\
\text { agencies rate between AAA and to AA- . } \\
\text { In addition Resolution N 92, issued by the Board of the NBRB in June } 2004 \text { regulates the } \\
\text { country risk incurred by the banks. } \\
\text { The Rules to be used in calculating capital adequacy, liquidity, and maximum exposures } \\
\text { differentiate risks and liquidity levels for investment operations depending on the country in } \\
\text { which resources are placed,. According to the Rules, the risk of placing resources in foreign } \\
\text { states and their liabilities (guarantees, collateral) are evaluated differently when calculating } \\
\text { capital adequacy and liquidity depending on the group of states that are OECD member } \\
\text { countries, countries that are not OECD members, and countries and territories that are offshore } \\
\text { zones. } \\
\text { Control is maintained over compliance with this limit. } \\
\text { established limits is carried out by the NBRB when it receives the relevant reports from banks } \\
\text { and when it conducts on site inspections. }\end{array}$ \\
\hline & |viateria \\
\hline
\end{tabular}




\begin{tabular}{|c|c|}
\hline ients & $\begin{array}{l}\text { Instruction } 92 \text { dated June } 2004 \text {, will become effective only in January } 2005 \text {. The effectiveness } \\
\text { of its implementation cannot be analyzed at the present time. } \\
\text { Also, individual banks have not established specific country exposure limits and transfer risk } \\
\text { limits on their operations in order to minimize country risk and transfer risk in international } \\
\text { lending and investment activities and therefore the Principle is assessed as Materially non- } \\
\text { compliant. } \\
\text { It is recommended that for purposes of establishing a limit for the total exposure of a bank to } \\
\text { country risk no distinctions be made between nonresident banks, and non resident government } \\
\text { agencies, nonresident corporation or individuals. } \\
\text { Financial institutions should be required to provide to the BSD, with periodic frequency } \\
\text { appropriate to the level of risk, information on their exposures to country risk using the rating } \\
\text { classification system specified by the NBRB. The Supervisors, at the onsite examinations } \\
\text { should make sure that the banks, in addition to any credit information on loans or investeents } \\
\text { in foreign institutions, have full credit information on any foreign institution where } \\
\text { correspondent demand balances or time deposits are being held. } \\
\text { Upon the implementation of the specific country exposure and transfer risk limits by the banks, } \\
\text { and the verification during the onsite examination process by the BSD examiners of the banks' } \\
\text { compliance with the newly established internal guidelines and with Instruction 92, a } \\
\text { reassessment of CP } 11 \text { will be warranted. }\end{array}$ \\
\hline Principle 12. & $\begin{array}{l}\text { Banking supervisors must be satisfied that banks have in place systems that accurately } \\
\text { measure, monitor and adequately control market risks; supervisors should have powers to } \\
\text { impose specific limits and/or a specific capital charge on market risk exposures, if warranted. }\end{array}$ \\
\hline D & $\begin{array}{l}\text { The NBRB establishes the standard on foreign exchange risk open foreign exchange position } \\
\text { (OEP) in accordance with Article } 117 \text { of the Banking Code. } \\
\text { Foreign exchange risk is regulated in accordance with Instructions on the Procedure for Open } \\
\text { Foreign Exchange Position Management by Authorized Banks and Nonbank Credit and } \\
\text { Finance Institutions of the Republic of Belarus, approved by NBRB Supervisory Board } \\
\text { Resolution No. 57, dated March } 29,2002 \text {, by establishing an OEP standard for banks as the } \\
\text { percent ratio of an authorized bank's OEP to capital. The overall value of the OEP for all } \\
\text { foreign currencies must not exceed } 20 \text { percent of an authorized bank's capital. Moreover, the } \\
\text { OEP for each foreign currency individually must not exceed } 10 \text { percent of an authorized bank's } \\
\text { capital; the OEP for forward transactions in respect to each foreign currency taken separately } \\
\text { must not exceed } 10 \text { percent of an authorized bank's capital. } \\
\text { The NBRB has issued Recommendations on Organizing Systems of Internal Control of } \\
\text { Banking Risks in Banks, which specify the main risks created by decisions of administrative } \\
\text { staff that have to be covered by control procedures, to include foreign exchange risk. } \\
\text { Instruction } 92 \text {, dated June } 26,2004 \text {, to take effect on January } 1,2005 \text { establishes a capital } \\
\text { charge on the market risks of banks. The operational details are being implemented at the } \\
\text { banks to take effect in January } 2005 \text {. Financial markets continue to be insufficiently developed } \\
\text { in the Republic of Belarus and the amount of banks assets exposed to market risk will probably } \\
\text { be negligible. }\end{array}$ \\
\hline
\end{tabular}




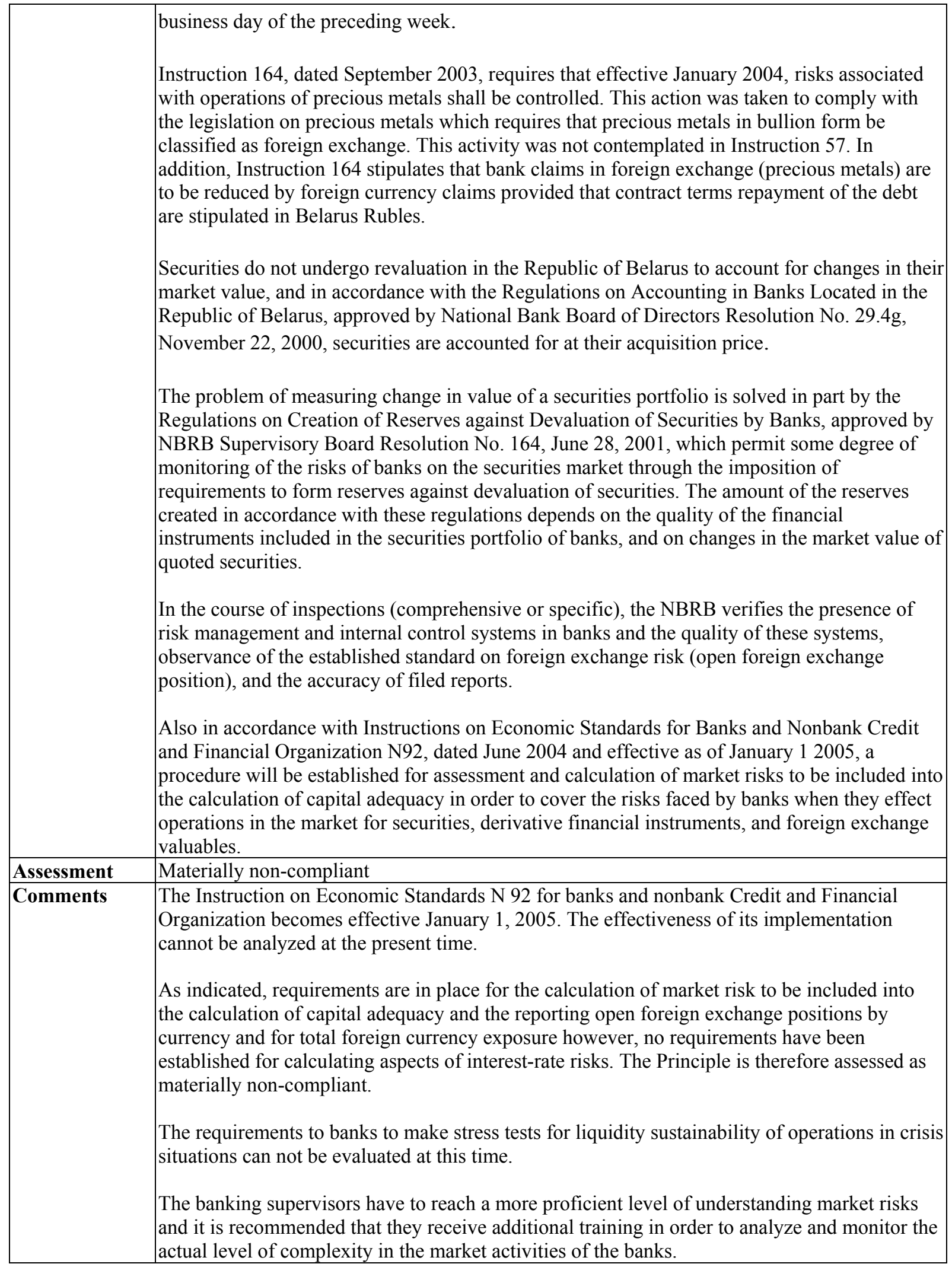




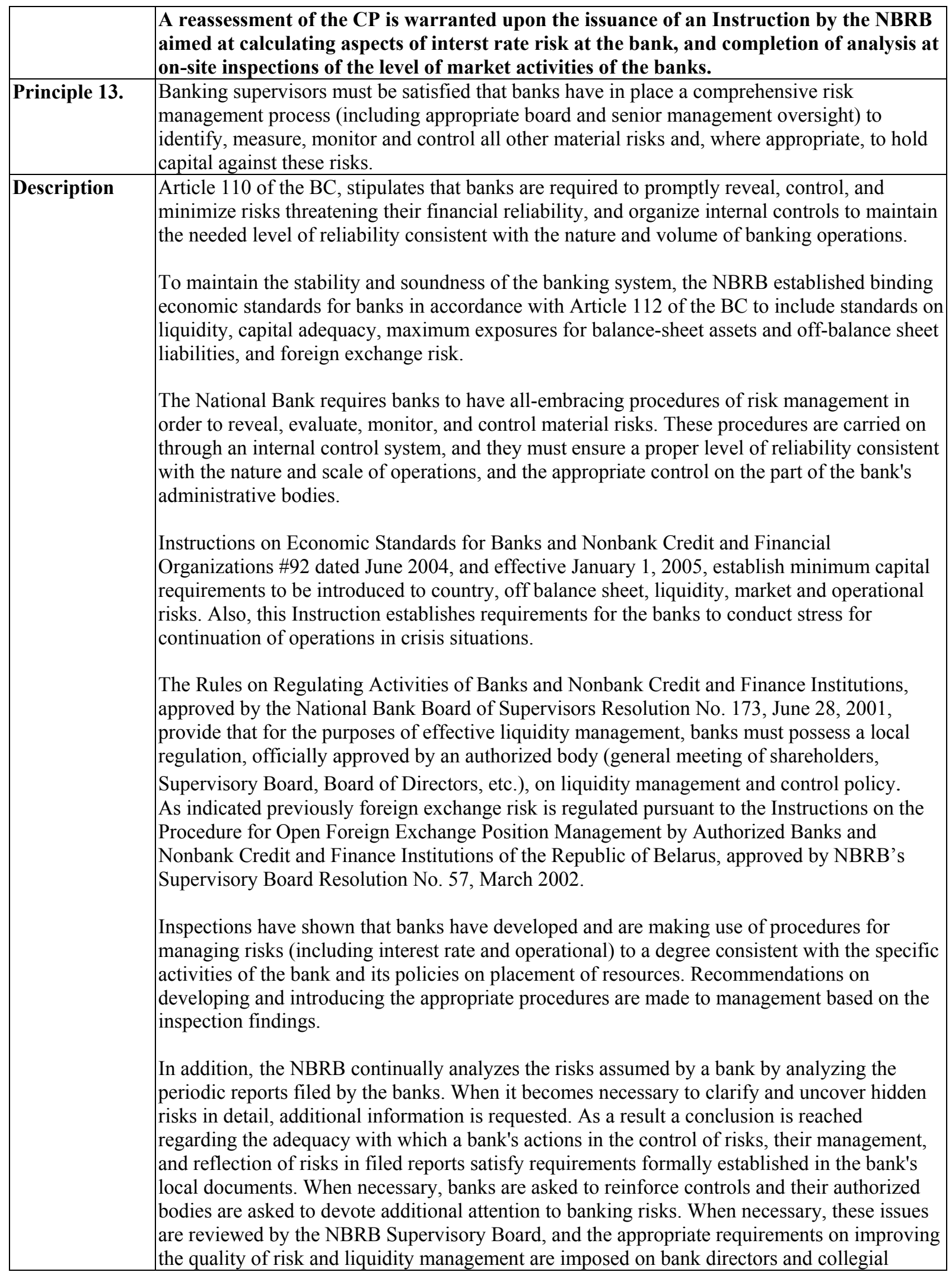




\begin{tabular}{|c|c|}
\hline & $\begin{array}{l}\text { administrative bodies. } \\
\text { According to NBRB Supervisory Board Resolution No. 176, June 28, 2001, banks may } \\
\text { provide interested persons the information on compliance with economic standards, and on the } \\
\text { amount and adequacy of special loss reserves for bank assets exposed to credit risk. Also, by } \\
\text { decision of a bank's authorized body, other information may be released in order to evaluate } \\
\text { the bank. }\end{array}$ \\
\hline Assessment & Materially non-compliant \\
\hline Comments & $\begin{array}{l}\text { The Instruction on Economic Standards for banks and nonbank Credit and Financial } \\
\text { Organization becomes effective January } 1,2005 \text {. The effectiveness of its implementation } \\
\text { cannot be analyzed at the present time, and the Principle is assessed as Materially non- } \\
\text { compliant. } \\
\text { Development of recommendations on operational risk management have not been } \\
\text { implemented. It is anticipated that the Conceptual Framework for Development of Banking } \\
\text { Supervision and the Plan of Measures to Introduce International Standards of Banking } \\
\text { Supervision in } 2005 \text { will address this issue. } \\
\text { The liquidity risk management process that includes among other the identification, measure, } \\
\text { monitoring and control of liquidity requires significant improvement in a number of banks. }\end{array}$ \\
\hline Principle 14. & $\begin{array}{l}\text { Banking supervisors must determine that banks have in place internal controls that are } \\
\text { adequate for the nature and scale of their business. These should include clear arrangements } \\
\text { for delegating authority and responsibility; separation of the functions that involve committing } \\
\text { the bank, paying away its funds, and accounting for its assets and liabilities; reconciliation of } \\
\text { these processes; safeguarding its assets; and appropriate independent internal or external audit } \\
\text { and compliance functions to test adherence to these controls as well as applicable laws and } \\
\text { regulations. }\end{array}$ \\
\hline Description & $\begin{array}{l}\text { The responsibilities of the Board of Directors (Supervisory Board of a bank) are set forth in the } \\
\text { Civil Code and in the Law on Joint-Stock Companies, Limited Liability Companies, and } \\
\text { Supplemental Liability Companies. } \\
\text { According to the Republic of Belarus Civil Code (Article 103), the authority of the Board of } \\
\text { Directors is determined by the charter. The Law on Joint-Stock Companies provides that } \\
\text { powers not described by law (including risk management functions) shall be specified in the } \\
\text { charter. } \\
\text { Article } 73 \text { of the BC, requires that a bank's charter must contain information on administrative } \\
\text { bodies, including executive and internal control bodies, and the procedure for forming these } \\
\text { bodies and their powers. } \\
\text { Article } 110 \text { of the Banking Code, to ensure financial reliability banks are required to promptly } \\
\text { reveal, control, and minimize risks endangering their financial reliability, and organize internal } \\
\text { controls ensuring the needed level of reliability consistent with the nature and volume of } \\
\text { banking operations. } \\
\text { The Republic of Belarus Law "On Measures To Prevent Legalization of Criminal Proceeds" } \\
\text { makes it a requirement that persons carrying out financial operations, including banks, must } \\
\text { develop regulations and measures of internal control of financial operations that are subject to } \\
\text { special control and are associated with legalization (laundering) of criminal proceeds. } \\
\text { The NBRB requires banks to have comprehensive risk management procedures permitting } \\
\text { revaluation, evaluation, monitoring, and control of material risks. }\end{array}$ \\
\hline
\end{tabular}




\begin{tabular}{|c|c|}
\hline & 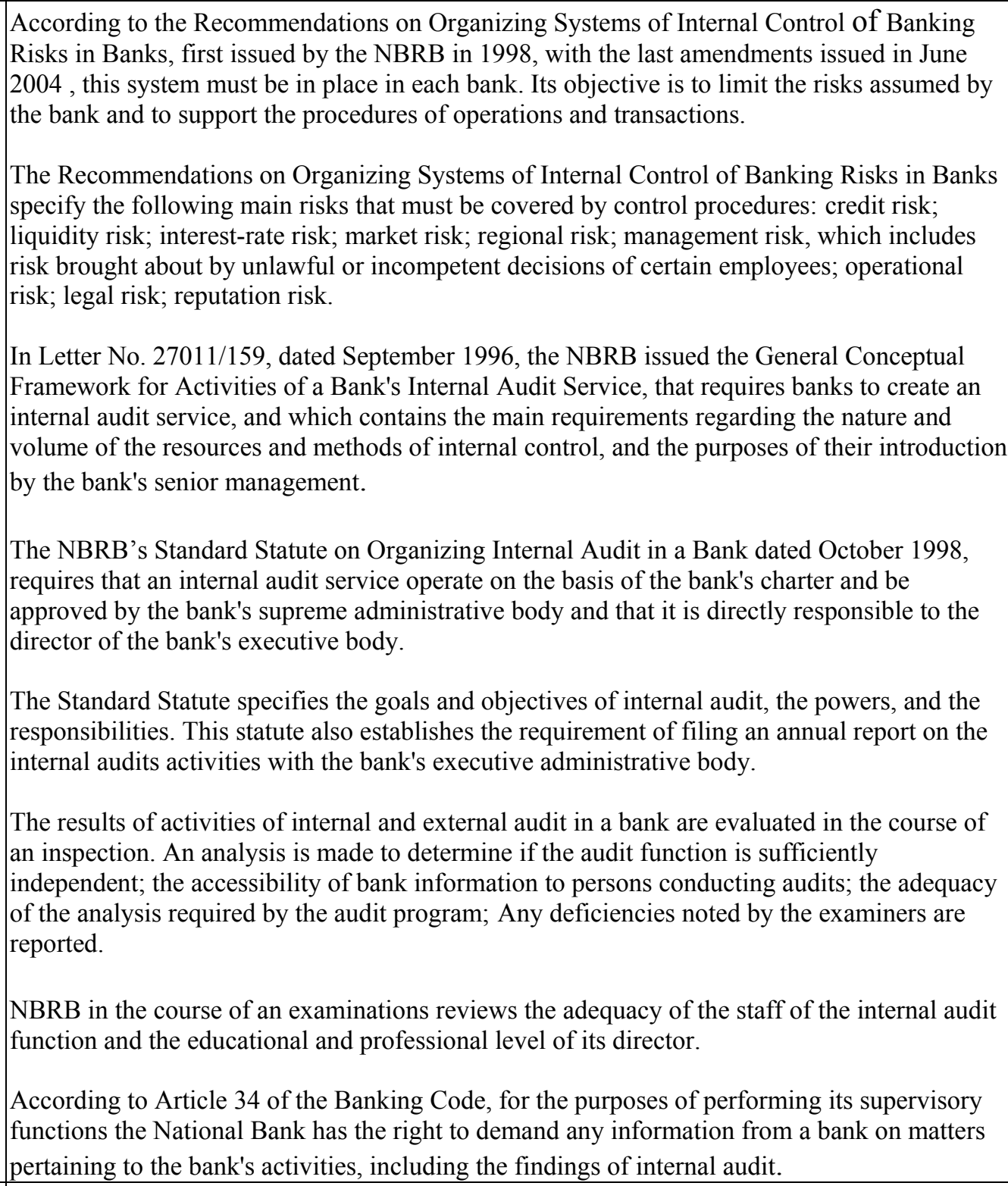 \\
\hline Assessment & Largely compliant \\
\hline Comments & $\begin{array}{l}\text { The Principle fulfills most of the essential criteria and is considered Largely compliant. } \\
\text { The Head of Internal Auditing should report directly to member of the bank's supreme } \\
\text { administrative body board of directors, also the NBRB does not have the right to evaluate } \\
\text { members of bank oversight councils, or the right to apply measures of supervisory influence } \\
\text { against them. }\end{array}$ \\
\hline \begin{tabular}{|l} 
Principle 15. \\
.
\end{tabular} & $\begin{array}{l}\text { Banking supervisors must determine that banks have adequate policies, practices and } \\
\text { procedures in place, including strict "know-your-customer" rules, that promote high ethical } \\
\text { and professional standards in the financial sector and prevent the bank being used, } \\
\text { intentionally or unintentionally, by criminal elements. }\end{array}$ \\
\hline \begin{tabular}{|l|} 
Description \\
\end{tabular} & $\begin{array}{l}\text { The Law of the Republic of Belarus "On Measures To Prevent Legalization of Criminal } \\
\text { Proceeds" (AML Law) issued in May } 2002 \text { requires persons carrying out financial operations , } \\
\text { including banks, to develop the regulations and measures of internal control of financial } \\
\text { operations that are subject to special control and are associated with legalization (laundering) }\end{array}$ \\
\hline
\end{tabular}


of criminal proceeds.

In keeping with the law, to ensure the banking system's stability and to protect it from infiltration by criminal capital, and accounting for international experience and the recommendations of the Financial Action Task Force on Money Laundering (FATF) and the Basle Committee on Banking Supervision, the NBRB has developed Recommendations on Organizing Systems of Internal Control in Banks (Nonbank Credit and Finance Institutions) covering the "know-your-customer" rule.

Recommendations require that when a bank organizes its system of internal controls it must have adequate policy, practice, and procedures in place, including clear rules ensuring observance of high ethical and professional standards that would prevent intentional or unintentional involvement of the bank in unlawful financial operations.

In accordance with requirements of the AML Law, a bank's system of internal controls includes control aimed at preventing and stopping actions connected with legalization of criminal proceeds. Article 4 of the above Law provides a list of operations subject to special controls.

In order to establish such a system of internal controls, a bank is required to develop and approve an internal documents specifying the procedure for identifying customers, revealing unlawful financial operations and financial operations subject to special controls, and registering the latter in accordance with legislation, and the document storage procedure.

The bank is required to appoint an official responsible for internal control. (The Law does not indicate that it should be a senior official.) Besides that, when it organizes its system of internal controls the bank must ensure the participation of all bank employees in reporting illegal financial operations, regardless of the positions they hold and within the limits of their authority.

Article 6 of the AML Law indicates that persons engaging in financial operations are released from liability for losses and resulting from lawful performance of their responsibilities.

Article 8 of this Law specifies that when The Financial Monitoring Department, created after the Law to prevent money laundering was implemented, establishes the existence of an illegal financial operation, it has the right to suspend such an operation by the established procedure, and take steps to bring the person or persons involved to accountability.

In keeping with the Instructions on the Procedure for Organizing Inspections of Banks, Their Branches (Offices), Representative Offices, and Nonbank Credit and Finance Institutions, approved by NBRB Supervisory Board Resolution No. 8.12, issued March 2000, and with the Methodological Recommendations on Organizing Inspections of Banks approved by the NBRB Board of Directors Resolution No. 209, dated June 2002, in the course of its inspections the NBRB checks for the presence of, and evaluates, the risk management and internal control systems of banks, including controls having the purpose of preventing the bank's involvement in illegal financial operations, and the quality of these systems.

The BSD prepares two separate Reports of Examination covering their on site inspection: a Regulatory Report, and Financial Report. The Regulatory Report will reflect the details of any violations of regulations. This report will have the information on all infractions of the various Laws, Regulations etc., including the AML Law. The Financial report, will contain the comments, if any are necessary, on the weaknesses of controls in this area. 


\begin{tabular}{|c|c|}
\hline & $\begin{array}{l}\text { NBRB Recommendations on Organizing Systems of Internal Control in Banks (Nonbank } \\
\text { Credit and Finance Institutions) in Fulfillment of the "Know Your Customer" Rule, No. 23- } \\
\text { 14/7290, May 30, } 2002 \text { suggests (directs) the banks to devote particular attention to financial } \\
\text { operations of legal entity customers registered or possessing branches or representative offices } \\
\text { in offshore zones, or registered in countries known to have illegal narcotics production on their } \\
\text { territory and known to cooperate with terrorist organizations. }\end{array}$ \\
\hline Assessment & Materially non-compliant. \\
\hline Comments & $\begin{array}{l}\text { The above assessment reflects the evaluation of the implementation, adequacy and } \\
\text { effectiveness of the anti money laundering procedures and "know your customer" rules. It } \\
\text { incorporates the findings to the BCP assessment and the findings of the Assessment of } \\
\text { AML/CFT. } \\
\text { The main functions of controlling compliance with requirements of the Law "On Measures to } \\
\text { Prevent Legalization of Criminal Proceeds" are not assigned to the NBRB but to the Ministry } \\
\text { of Taxes and Duties and the State Control Committee of the Republic of Belarus. Bank } \\
\text { supervisors need to place more emphasis on detection, deterrence, and reporting of suspicious } \\
\text { transactions. Financial intelligence needs to be centralized in a single agency and provisions } \\
\text { for international cooperation need to be strengthened. } \\
\text { Because the National Bank is not the main controlling body in respect to observance of } \\
\text { requirements of the Law "On Measures to Prevent Legalization of Criminal Proceeds," its } \\
\text { functions do not include establishment of requirements on training the appropriate specialists } \\
\text { in banks and providing expert assistance to them in revealing cases of fraud, legalization of } \\
\text { proceeds, and other illegal financial operations. The BSD is conscious of the possibility that } \\
\text { financial institutions might be engaged, intentionally or unintentionally, in money laundering } \\
\text { activities and attention is given to this area during the onsite examination. } \\
\text { The NBRB due to its expertise in banking activities has conducted seminars at its Training } \\
\text { Center attended by the Law Officers of the other Agencies involved in the effort to prevent } \\
\text { money laundering. NBRB personnel has attended seminars on prevention of money } \\
\text { laundering. }\end{array}$ \\
\hline Principle 16. & $\begin{array}{l}\text { An effective banking supervisory system should consist of some form of both on-site and off- } \\
\text { site supervision. }\end{array}$ \\
\hline Description & $\begin{array}{l}\text { Article } 34 \text { of the BC states that the NBRB shall exercise continuous control over observance of } \\
\text { banking laws by banks and nonblank financial and credit institutions. The BSD has developed } \\
\text { the Methodological Recommendations on Comprehensive Analysis of a Bank's Financial } \\
\text { Condition, approved by the NBRB Supervisory Board Resolution No. 208, dated June 25, } \\
\text { 2002. These Recommendations implemented a comprehensive approach to assess the financial } \\
\text { condition of a bank and reveal risks in banking activities at their inception. The analysis results } \\
\text { are used to arrive at decisions that include the frequency of onsite inspections, the } \\
\text { determination of the areas to be inspected, and of the nature of supervisory measures to be } \\
\text { applied to the bank. } \\
\text { Information obtained in the course of inspections is used to assess the financial condition of a } \\
\text { credit institution and select supervisory response measures. } \\
\text { Article } 37 \text { of the BC, requires banks and nonbank credit and finance institutions to provide the } \\
\text { NBRB, with financial and economic information and documentation necessary for the BSD } \\
\text { performance of its functions. } \\
\text { In accordance with Article } 120 \text { of the Banking Code, banks file periodic reports, (daily, } \\
\text { weekly, monthly, quarterly and annual basis) with the NBRB covering their various activities. }\end{array}$ \\
\hline
\end{tabular}


The BSD consists of 62 specialists, inspectors and analysts of whom 62 are located at the NBRBBRB headquarters in Minsk. 67 staff located at the 6 regional offices undertake inspections of bank branches and report to the BSD.

The on-site supervision activities are carried out by the Inspection Department, which consist of three Divisions: a) the Asset Quality Assessment and Profitability Division; b) the Capital adequacy and Liquidity Inspection Division and c) the Administration and Risk Management Assessment Division.

Off site supervision is conducted by Supervision Organization Department that also cosists of three Divisions: a) Division of Personal Supervision over Authorized Banks; b) Division of Personal Supervision Over Non Authorized Banks and c) Division of Personal Supervision over Crisis Banks.

These two Departments are complemented by the Licencing and Registration Division, and the Departments of Information and Analysis and Methodology of Supervision Department.

The Department's main objective is to : analyze the financial condition of the banks, the risks taken by management, the adequacy of the internal control system, adherence to established prudential requirements, accuracy of accounting transactions, and reliability of reports submitted to the NBRB.

Complying with the Instructions on the Procedure for Organizing Inspections of Banks, approved by NBRB's Supervisory Board Resolution No. 8.12, of March 2000, the BDS performs the following functions: conducts inspections with the purpose of establishing, directly on-site, the real financial condition of a bank, the risks it assumes, the status of the system of internal controls, the organization of management, the bank's fulfillment of established prudential requirements, the correctness with which operations are shown in bookkeeping records, and the accuracy of reports filed with the NBRB; revealing situations endangering the interests of creditors and depositors, violations of legislation regulating banking activities and of the charter and internal documents of a bank, and their causes and the conditions under which they were committed; and when necessary, generating recommendations on making corrections in the work of a bank, correcting revealed deficiencies and preventing them in the future, taking corrective actions against a bank, and bringing its officials to accountability.

Comprehensive inspections of each bank are conducted on site over a two year cycle to evaluate the financial soundness of a bank, the efficiency of its activities, and the adequacy of evaluating the risks it assumes. Great significance is attached in inspections to evaluation of the quality of management in a bank, to verification of the presence of risk management and internal control systems in banks and to inspection of the quality of these systems. Issues concerned with liquidity management and the correctness of preparation of liquidity reports are considered during comprehensive inspections of banks. Analysis of risks, their identification, and the methods of their minimization by a bank are checked. The inspection program addresses the presence of an action program for the event of unforeseen circumstances.

During preparations for an onsite inspection, the results of off-site supervision are analyzed in order to determine the areas of a bank's activity presenting the more serious problems. In addition the BSD staff in Minsk supervises and coordinates the activities of the staff of the NBRB, offices located in the other regions of the country.

In addition the BSD reviews the observance of established economic standards, the correctness of asset classification, and the completeness of creation of loss reserves for assets are controlled in compliance with, and on the basis of reports prescribed by, the Rules On 
Regulating Activities of Banks and Nonbank Credit and Finance Institutions approved by NBRB Supervisory Board Resolution No. 173, of June 2001, Instructions on the Procedure for Open Foreign Exchange Position Management by Authorized Banks and Nonbank Credit and Finance Institutions of the Republic of Belarus approved by NBRB Supervisory Board Resolution No. 57, March 29, 2002, the Regulations on Forming and Using Special Loss Reserves for Assets of a Bank and a Nonbank Credit and Finance Institutions Exposed to Credit Risk approved by NBRB Supervisory Board Resolution No. 33, February 19, 2001, and the Regulations on Creation of Reserves against Devaluation of Securities by Banks approved by NBRB Supervisory Board Resolution No. 164, June 28, 2001.

Other departments of the NBRB assist the BSD examiners at the onsite examinations.

Upon completion of an inspection two reports are prepared. One report cover the Regulatory Aspects Review conducted by the BSD, and the other is a financial report that covers all the components of a CAMELS assessment. A review of four examination reports indicated that the examiners have a good degree of proficiency in analyzing the operations of a bank.

The results of both external and internal audits are utilized by the BSD in their supervision of banks. Based on Article 34 of the Banking Code, the National Bank has the right to require a bank or a nonbank credit and finance institutions to have the external auditing organization certify the annual report, all reports covering shorter periods, and other reports, and to file the auditor's opinion unabridged. As required by the NBRB Letter No. 27, of February 2002 "On the Procedure and Times of Public Release of Bank Annual Reports", an external audit's opinion on the accuracy of a bank's annual report (balance sheet and profit/loss statement) is filed obligatorily with the NBRB.

According to articles 34 and 122 of the BC, and item 160 of Republic of Belarus Council of Ministers Resolution No. 237, February 15, 1999 "On Restricted Official Information," the NBRB does not have the right to disclose information obtained in the course of banking supervision, except in cases prescribed by law.

Inspections of banks and their branches are conducted on the basis of inspection plans. Unscheduled inspections are conducted as necessary. The Methodological Recommendations on Organizing and Conducting Inspections of Banks (approved by Republic of Belarus National Bank Supervisory Board Resolution No. 209, June 25, 2002) were developed to optimize the conduct of inspections.

The BSD examiners located at the Main Office of the NBRB, primarily examine the Head Offices of all the banking institutions located in Minsk. The examination of the branches of these banks is conducted by the Minsk Regional Office and the examiners located at the other five regional offices.

\begin{tabular}{|l|l|}
\hline Assessment & Largely compliant
\end{tabular}

\begin{tabular}{|l|l}
\hline Remarks & The NBRB has a supervisory system in which the BSD's off-site analysts and on-site
\end{tabular} inspectors work in close cooperation and thus are able to arrive at a qualitative identification and understanding of the risks faced by the institutions they examine. On-site inspectors as well as analysts are well trained. A brief review of a few of the latest reports of examination indicates that the on-site examiners utilize the equivalent of a CAMELS system to inspect the banks and cover adequately the Capital, Assets, Management, Earnings, Liquidity and Sensitivity to Risk components and are doing a competent job in providing an objective evaluation of the quality of an institution, and identifying areas where corrective action is required to strengthen the bank.

The evaluation of the various components used to analyze the financial institutions is a mix of 


\begin{tabular}{|c|c|}
\hline & $\begin{array}{l}\text { quantitative and qualitative judgment } \\
\text { However, an essential element of banking supervision is the ability of the supervisors to } \\
\text { supervise banking groups on a consolidated basis. As indicated in CP 20, the NBRB } \\
\text { supervisors do not have the authority to request and obtain information on the make up of a } \\
\text { banking group. The NBRB has prepared a draft in order to introduce amendments to the BC in } \\
\text { this area. Also, the annual Government recapitalization of some state owned banks raises the } \\
\text { question of the accuracy of the information provided by some banks in their published annual } \\
\text { financial statements. The BSD supervisors should accelerate the transition to International } \\
\text { Financial Reporting Standards(IFRS) by the banking sector. In addition the BSD should } \\
\text { introduce an early warning system that focuses among other, on liquidity demand and } \\
\text { intermediation. }\end{array}$ \\
\hline Principle 17. & $\begin{array}{l}\text { Banking supervisors must have regular contact with bank management and thorough } \\
\text { understanding of the institution's operations. }\end{array}$ \\
\hline Description & $\begin{array}{l}\text { According to the Instructions on the Procedure for Organizing Inspections of Banks, issued } \\
\text { March 2002, and the Methodological Recommendations on Organizing Inspections of Banks, } \\
\text { issued, June 2002, one of the main objectives of bank inspections is to assess the quality of } \\
\text { management with the goal of determining the extent to which a bank's senior management } \\
\text { possesses the necessary experience and skills allowing it to cope with changing business } \\
\text { conditions and manage risks in market conditions. } \\
\text { BSD officers and employees hold meetings with senior and middle management of banks to } \\
\text { discuss inspection results and problems uncovered in the supervision of the bank's activities. } \\
\text { In addition, meetings with executives of banks exhibiting certain difficulties in their work are } \\
\text { planned in conjunction with meetings of the Committee to Support Stability of the Banking } \\
\text { System, organized in } 2002 \text {. Also, the Director of the BSD holds throughout the year meetings } \\
\text { with the senior officers of all } 31 \text { banks in the country. } \\
\text { Article } 81 \text { of the BC, requires that prior to adoption of a decision on state registration and } \\
\text { issuance of a license to a bank, the NBRB evaluates the professional fitness of the directors of } \\
\text { executive bodies and the chief accountant. }\end{array}$ \\
\hline Assessment & Compliant \\
\hline \begin{tabular}{|l|} 
Comments \\
\end{tabular} & $\begin{array}{l}\text { The NBRB inspectors have frequent formal and informal contact with each institution's } \\
\text { middle management during the onsite examinations process in order to have a better } \\
\text { understanding of the bank's practices or to better understand problems in individual situations. } \\
\text { During these on site examinations the supervisors consider the quality of management. Also, } \\
\text { through a combination of onsite inspections and off site surveillance the supervisors have a } \\
\text { good understanding of the activities of all institutions in the banking system and meetings with } \\
\text { the bank's Board and/or management are a part of the supervisory process. } \\
\text { While not part of a program of regular meetings, the head of the BSD has recurrent meetings } \\
\text { with senior management of all the banks to discuss operational matters, such as performance, } \\
\text { capital adequacy, liquidity and risk management systems etc. } \\
\text { Banks make it a practice to provide advance notification of operations that may lead to a } \\
\text { violation of prudential requirements for the purposes of avoiding imposition of sanctions by } \\
\text { the NBRB. }\end{array}$ \\
\hline Principle 18. & $\begin{array}{l}\text { Banking supervisors must have a means of collecting, reviewing and analyzing prudential } \\
\text { reports and statistical returns from banks on a solo and consolidated basis. }\end{array}$ \\
\hline \begin{tabular}{|l|} 
Description \\
\end{tabular} & $\begin{array}{l}\text { Effective January } 1,2005 \text {, the procedure for compilation and submission of financial reports } \\
\text { will be regulated by the "Instruction on Procedure for Compilation of Prudential Reports by } \\
\text { Banks and Nonbank Credit and Financial Organizations and their Submission to the NBRB" } \\
135 \text {, approved in August } 2004 \text {. }\end{array}$ \\
\hline
\end{tabular}


This Instruction assembles the requirements to the procedures of compilation and submission of prudential reports submitted to the NBRB for the purposes of conducting supervision functions.

In accordance with Article 120 of the BC, banks file financial report as required by the NBRB. In the performance of supervisory functions, the National Bank has the right to request and obtain from banks any necessary information on their activity. The accuracy of reports is evaluated in the course of analysis of a bank's financial condition and during inspections.

In accordance with Article 26 of the BC, the NBRB develops and approves the methods of accounting and reporting for banks. The procedure for compiling and filing reports on the activities of banks also falls under the authority of the NBRB .

The procedure for compiling and filing prudential reports by banks is established by the Rules on Regulating Activities of Banks and Nonbank Credit and Finance Institutions approved by the NBRB Supervisory Board Resolution No. 173, dated June 2001. Instructions on the Procedure for Open Foreign Exchange Position Management by Authorized Banks and Nonbank Credit and Finance Institutions of the Republic of Belarus was approved by the NBRB Supervisory Board Resolution No. 57, March 2002; Regulations on Forming and Using Special Loss Reserves for Assets of a Bank and a Nonbank Credit and Finance Institutions Exposed to Credit Risk were approved by the NBRB Supervisory Board Resolution No. 33, February 2001, and the Regulations on Creation Reserves against Devaluation of Securities by Banks, were approved by the Supervisory Board Resolution No. 164, June 28, 2001. These forms provide information on compliance of banks with established economic standards, including capital adequacy, liquidity and large exposures, asset classification, and the completeness of creation of loss reserves for assets, including reserves against devaluation of securities. In addition, these reports permit analysis of factors affecting the status of the relevant indicators of a bank's activities.

According to the Republic of Belarus Law "On Accounting and Reporting," the organization's director and the chief accountant are responsible for the accuracy of the reports submitted to the NBRB. When banks do not comply with the reporting procedures, the National Bank has the right to take corrective actions against a bank pursuant to Article 135 of the Republic of Belarus Banking Code.

The Methodological Recommendations on Comprehensive Analysis of a Bank's Financial Condition, approved by Republic of Belarus National Bank Supervisory Board Resolution No. 208, June 25, 2002 suggest a scheme for analyzing a bank's financial condition on the basis of both the prudential and financial reports it files.

Pursuant to the Rules on Regulating Activities of Banks and Nonbank Credit and Finance Institutions, the Regulations on Forming and Using Special Loss Reserves for Assets of a Bank and a Nonbank Credit and Finance Institutions Exposed to Credit Risk, and the Regulations on Creation of Reserves against Devaluation of Securities by Banks, banks send prudential reports to the National Bank at a frequency that depends on the frequency of control of observance of the relevant prudential requirements.

The frequency of filing financial reports is established in the Instructions on Compiling Financial Report Forms depending on the nature of the filed information and the frequency of its use for analysis of a bank's financial condition.

Effective January 1, 2005, the procedure for compilation and submission of financial reports will be regulated by the "Instruction on Procedure for Compilation of Prudential Reports by Banks and Nonbank Credit and Financial Organizations and their Submission to the NBRB" 


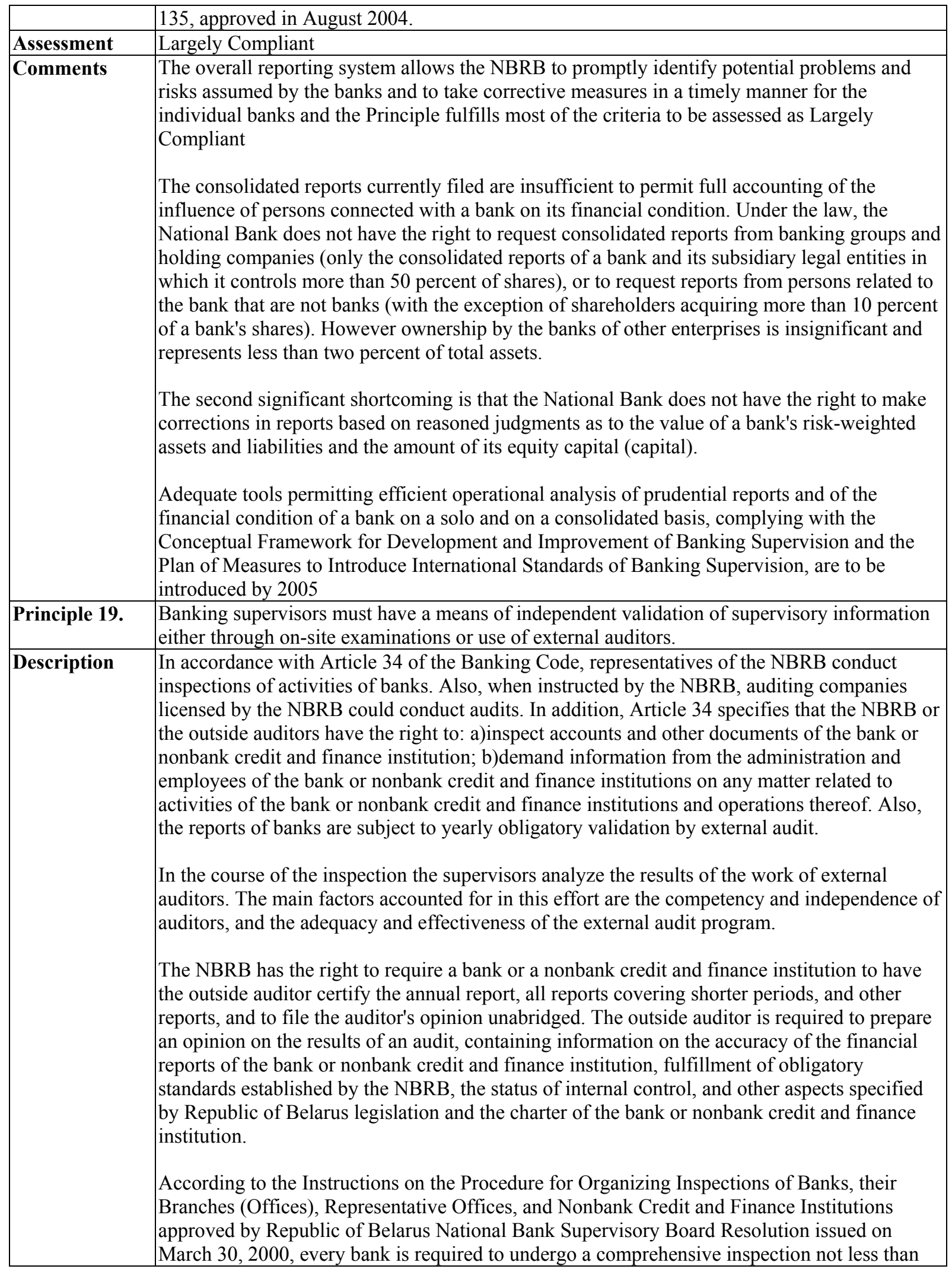




\begin{tabular}{|c|c|}
\hline & $\begin{array}{l}\text { once every three years. Banks known to be experiencing deterioration of their financial } \\
\text { condition, banks that have accepted higher risks, and banks that have violated banking } \\
\text { legislation are scheduled for examination at greater frequency. }\end{array}$ \\
\hline Assessment & Largely Compliant \\
\hline Comments & $\begin{array}{l}\text { The NBRB does not exercise its right to bring in external auditors to conduct inspections for } \\
\text { the purposes of banking supervision, instead carries out such inspections with the staff of its } \\
\text { own inspection subdivisions. } \\
\text { Meetings with senior management of banks to discuss the results of comprehensive } \\
\text { inspections, including the external audits, are held once every two years at the conclusion of } \\
\text { the onsite inspection. Trilateral meetings with senior management of banks and auditors to } \\
\text { discuss the results of an external audit are not conducted as a rule. } \\
\text { Regulations of the National Bank governing auditing in the banking system are in process of } \\
\text { revision, in order to incorporate the new risk based supervisory procedures provided for within } \\
\text { the framework of current legislation. The Principle complies with most of the essential criteria. }\end{array}$ \\
\hline Prin & $\begin{array}{l}\text { An essential element of banking supervision is the ability of the supervisors to supervise the } \\
\text { banking group on a consolidated basis. }\end{array}$ \\
\hline Des & $\begin{array}{l}\text { The legislation does not codify the possibility for conducting supervision on a consolidated } \\
\text { basis; the NBRB does not have the authority to request and obtain information on the makeup } \\
\text { of a banking group or bank holding company, to and analyze the activities of the legal entities } \\
\text { constituting them when such entities are supervised directly by other agencies. The NBRB } \\
\text { does not conduct inspections of the activities of parent companies, and it does not have the } \\
\text { right to take steps to issue recommendation to resolve difficulties in their financial condition. } \\
\text { There is no mechanism for evaluating risks of the subsidiaries and the authority to inspect all } \\
\text { areas of activity of a bank through its subsidiaries activities is not legislated. } \\
\text { Article } 120 \text { of the BC states that if a bank owns more than } 50 \text { percent of the voting shares of } \\
\text { another legal entity, it is required to file a consolidated report with the NBRB on its activities } \\
\text { and on the activities of its subsidiary subdivisions, to include a consolidated balance sheet and } \\
\text { a consolidated profit/loss statement, in a specified format, and at periodic intervals established } \\
\text { by the NBRB. } \\
\text { The structure of banking institutions is known to NBRB since the banks are required to notify } \\
\text { the National Bank of all instances of investment of equity capital in the authorized capital of } \\
\text { legal entities irrespective of the degree of participation. }\end{array}$ \\
\hline & Non-compliant \\
\hline Com & $\begin{array}{l}\text { The National Bank has prepared a draft in order to introduce amendments to the BC. The draft } \\
\text { introduces definitions of a banking group and a bank holding company, and allows NBRB the } \\
\text { possibility for supervising such groups and holding companies on a consolidated basis. This } \\
\text { draft provides for establishment of certain economic standards for banking groups/holding } \\
\text { companies, and establishes corrective actions to be taken by the NBRB for their violation. } \\
\text { Adoption of the proposed amendment to the BC will allow the NBRB to develop and } \\
\text { introduce the necessary mechanisms of supervision of the activities of banking groups and } \\
\text { holding companies on a consolidated basis. Until such time the Principle is assessed as Non- } \\
\text { compliant. }\end{array}$ \\
\hline Principle 21. & $\begin{array}{l}\text { Banking supervisors must be satisfied that each bank maintains adequate records drawn up in } \\
\text { accordance with consistent accounting policies and practices that enable the supervisor to } \\
\text { obtain a true and fair view of the financial condition of the bank and the profitability of its } \\
\text { business, and that the bank publishes on a regular basis financial statements that fairly reflect } \\
\text { its condition. }\end{array}$ \\
\hline Description & $\begin{array}{l}\text { According to Article } 34 \text { of the Banking Code, the NBRB has the right to require a bank or a } \\
\text { nonbank credit and finance institution to have an external auditing firm certify the annual }\end{array}$ \\
\hline
\end{tabular}


report, all reports covering shorter periods, and other reports, and to file the auditor's opinion unabridged.

The NBRB evaluates the accuracy of reports prepared by the outside auditors during the on site inspection, and offsite during the preparation of analysis of financial condition of the institution. According to Instruction No 8, approved by the NBRB in March 2000, on the Procedure for Organizing Inspections of Banks, Their Branches (Offices), Representative Offices, and Nonbank Credit and Finance Institutions, one of the goals of inspections is to evaluate the accuracy with which operations are shown in bookkeeping records, and the accuracy of reports filed with the National Bank. When doubts arise regarding the accuracy of filed reports, the supervisor may conduct a specific inspection on this matter.

According to the Republic of Belarus Law "On Accounting and Reporting," the organization's director is responsible for organizing bookkeeping and creating the necessary conditions for its proper management. The chief accountant is responsible for drawing up and maintaining accounts, shaping the organization's accounting policy, and compiling and promptly filing full and accurate accounting and tax reports.

Article 26 of the Banking Code, the Republic of Belarus National Bank details the procedures of accounting and reporting for banks and nonbank credit and finance institutions, taking in consideration international banking practice. In this connection the NBRB has issued the Regulations on Accounting in Banks Located in the Republic of Belarus, No. 29.4g, in November 2000.

The following international standards on financial reporting have been developed for the purposes of introducing international financial reporting standards into the Republic of Belarus:

National Financial Reporting Standard 1 "Filing of Financial Reports" (NSFO 1); National Financial Reporting Standard 7 "Report on Flow of Monetary Resources" (NSFO 7);

National Financial Reporting Standard 21 "Effect of Changes in Foreign Exchange Rates" (NSFO 21);

National Financial Reporting Standard 27 "Consolidated Financial Reports and Accounting for Investments in Subsidiary Structures” (NSFO 27);

National Financial Reporting Standard 28 “Accounting for Investments in Dependent Structures" (NSFO 28);

National Financial Reporting Standard 29 "Financial Reports in the Conditions of Hyperinflation" (NSFO 29);

National Financial Reporting Standard 30 "Financial Reports of Banks" (NSFO 30).

There is the practice, however, of releasing banks from liability for not creating the appropriate reserves in their full amount, which essentially gives a bank the right not to show the real losses from its activities.

In accordance with articles 26, 34, 37, and 120 of the Banking Code the Republic of Belarus National Bank developed the Regulations on Compilation and Filing of an Annual Report by Banks of the Republic of Belarus, No. 350, December 28, 2001, which require banks to file an annual report validated by an external auditor's opinion.

The Rules on Regulating Activities of Banks and Nonbank Credit and Finance Institutions, approved by the NBRB Supervisory Board Resolution No. 173, June 2001, the Instructions on the Procedure for Open Foreign Exchange Position Management by Authorized Banks and Nonbank Credit and Finance Institutions of the Republic of Belarus approved by NBRB's Supervisory Board Resolution No. 57, March 2002, the Regulations on Forming and Using 


\begin{tabular}{|c|c|}
\hline & 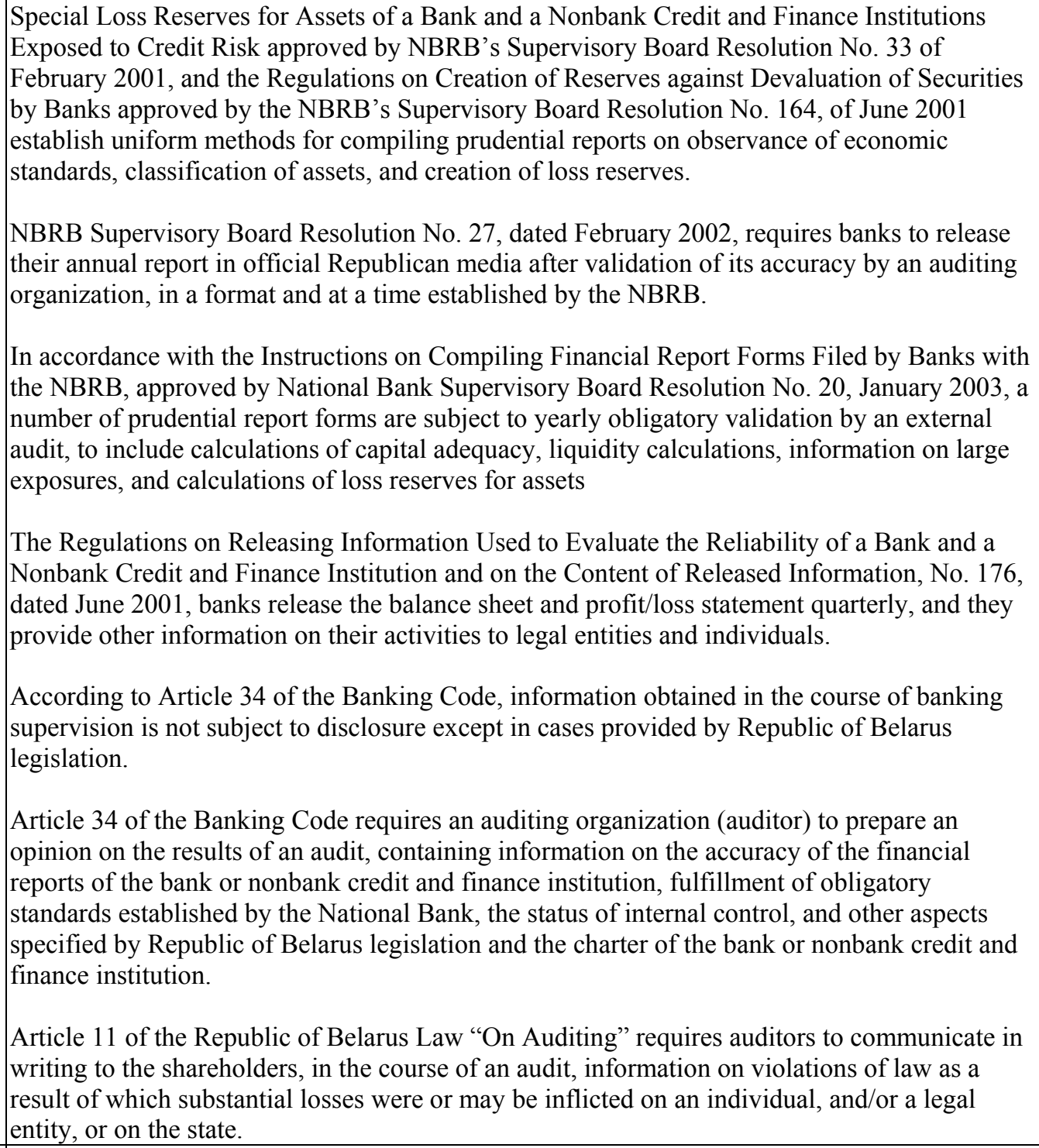 \\
\hline Asse & Materially non-compliant \\
\hline Comr & $\begin{array}{l}\text { International financial reporting standards have not been introduced to the full extent . In } \\
\text { particular, appraisal of assets and liabilities based on fair (market) value is not employed in } \\
\text { accounting. Carrying out an audit in accordance with international standards is not obligatory } \\
\text { in annual audits of banks. Until such conditions have been rectified, the Principle is assessed as } \\
\text { Materially non-compliant. } \\
\text { There is the practice of releasing banks from liability for not creating the appropriate reserves } \\
\text { in their full amount, which essentially gives a bank the right not to show the real losses from } \\
\text { its activities. Also, some of the state banks report earnings on their yearly financial reports, } \\
\text { however subsequently require capital injections from the Government } \\
\text { A rule allowing the National Bank to demand replacement of an outside auditor by a bank or a } \\
\text { nonbank credit and finance institution is not included in the legislation. Since the NBRB relies } \\
\text { almost exclusively on the work of the BSD inspectors for the onsite inspections, this matter is } \\
\text { of no consequence at this time. }\end{array}$ \\
\hline
\end{tabular}




\begin{tabular}{|c|c|}
\hline & $\begin{array}{l}\text { Auditors are not required to report information to the NBRB, that in their opinion may } \\
\text { be of interest to the BSD. This weakness is overcome by the requirement that bank } \\
\text { auditors must file a complete auditor's opinion with the NBRB on the results of a bank } \\
\text { inspection. Pending the introduction of International Financial Reporting Standards for } \\
\text { banks by the NBRB, and its implementation by the banks, this CP is considered as } \\
\text { Materially Non-compliant }\end{array}$ \\
\hline Com & $\begin{array}{l}\text { International financial reporting standards have not been introduced to the full extent . In } \\
\text { particular, appraisal of assets and liabilities based on fair (market) value is not employed in } \\
\text { accounting. Carrying out an audit in accordance with international standards is not obligatory } \\
\text { in annual audits of banks. Until such conditions have been rectified, the Principle is assessed as } \\
\text { Materially non-compliant. } \\
\text { There is the practice of releasing banks from liability for not creating the appropriate reserves } \\
\text { in their full amount, which essentially gives a bank the right not to show the real losses from } \\
\text { its activities. Also, some of the state banks report earnings on their yearly financial reports, } \\
\text { however subsequently require capital injections from the Government } \\
\text { A rule allowing the National Bank to demand replacement of an outside auditor by a bank or a } \\
\text { nonbank credit and finance institution is not included in the legislation. Since the NBRB relies } \\
\text { almost exclusively on the work of the BSD inspectors for the onsite inspections, this matter is } \\
\text { of no consequence at this time. } \\
\text { Auditors are not required to report information to the NBRB, that in their opinion may be of } \\
\text { interest to the BSD. This weakness is overcome by the requirement that bank auditors must file } \\
\text { a complete auditor's opinion with the NBRB on the results of a bank inspection. Pending the } \\
\text { introduction of International Financial Reporting Standards for banks by the NBRB, and its } \\
\text { implementation by the banks, this CP is considered as Materially Non-compliant. }\end{array}$ \\
\hline Pri & $\begin{array}{l}\text { Banking supervisors must have at their disposal adequate supervisory measures to bring about } \\
\text { timely corrective action when banks fail to meet prudential requirements (such as minimum } \\
\text { capital adequacy ratios), when there are regulatory violations, or where depositors are } \\
\text { threatened in any other way. }\end{array}$ \\
\hline Desc & $\begin{array}{l}\text { The powers of the National Bank to apply supervisory response measures against credit } \\
\text { institutions are specified by Articles } 97 \text { and } 135 \text { of the BC, the Republic of Belarus Law No. } \\
\text { 423-Z, Article 181, dated August } 2000 \text { "On Economic Insolvency (Bankruptcy)" } \\
\text { NBRB Supervisory Board Resolution No. 3, and No 4, dated January } 2001 \text { "On Approving } \\
\text { Regulations on Corrective Actions Taken by the National Bank against Banks and Nonbank } \\
\text { Credit and Finance Institutions" and "On Approving Regulations on Appointment and } \\
\text { Termination of the Activity of an Interim Administration to Manage a Bank or a Nonbank } \\
\text { Credit and Finance Institution"; } \\
\text { NBRB Supervisory Board Resolution No. 71, March 29, } 2001 \text { "On Approving Regulations on } \\
\text { Placement of a Bank or Nonbank Credit and Finance Institution under the Temporary } \\
\text { Management of the Republic of Belarus National Bank." } \\
\text { In the event of violation of current legislation, economic standards, or orders of the NBRB, the } \\
\text { NBRB has the right to apply the following corrective actions: } \\
\text { require correction of revealed violations; } \\
\text { collect fines of amounts established by the National Bank; } \\
\text { suspend the licenses of a bank or a nonbank credit and finance institution pertaining } \\
\text { demand implementation of measures for financial recovery of a bank or a nonbank } \\
\text { to particular banking operations for up to one year; } \\
\text { credit and finance institution, to include changes to the structure of assets; }\end{array}$ \\
\hline
\end{tabular}


submit proposals for the replacement of their directors or for re-evaluation of the professional fitness of the directors of executive bodies and the chief accountant; require removal of the bank director from his position; demand reorganization of the bank or nonbank credit and finance institution; change economic standards for a bank or nonbank credit and finance institution for a period of up to one year, or until violations are corrected; impose a prohibition on the opening of branches (offices) as well as structural subdivisions away from the bank's or nonbank credit and finance institution's location for a period of up to one year, or until violations are corrected; corrected; suspend banking licenses for a period of up to one year, or until violations are

revoke licenses for particular banking operations;

place a bank or nonbank credit and finance institution under the temporary management of the National Bank, or appoint an interim administration by procedure established by Republic of Belarus legislation.

The NBRB has the right to impose administrative punishments on officials of a bank or nonbank credit and finance institution pursuant to Republic of Belarus legislation.

The NBRB has the right to collect fines without contest from a bank or a nonbank credit and finance institution.

In accordance with Republic of Belarus Law “On Economic Insolvency (Bankruptcy)" (Article 181), the NBRB has the right to implement the following measures to keep a bank from going into bankruptcy in cases established by this law:

improve the financial condition of the bank;

appoint an interim administration to manage the bank (henceforth -- interim

administration); reorganize the bank.

If the grounds for implementing measures to keep a bank from going into bankruptcy arise, its stockholders are required to take the necessary steps to improve the bank's financial condition or to reorganize the bank.

If the grounds for implementing measures to keep a bank from going into bankruptcy arise, the Republic of Belarus National Bank has the right to require the bank to implement measures to improve the bank's financial condition or to reorganize the bank, and to appoint an interim administration.

According to the Banking Code (Article 135) and the Regulations on Corrective Actions Taken by the NBRB against Banks and Nonbank Credit and Finance Institutions, when the actions of a bank (the administrative bodies thereof) have led to creation of a situation that may cause the bank to become insolvent or endanger the interests of a bank's depositors and creditors, the supervisor has a right to submit proposals on replacing senior management or reevaluating the professional fitness of the directors of executive bodies, or demand dismissal of the bank director.

The results of evaluating bank senior management with the purpose of determining the extent to which it possesses the needed experience and skills allowing it to cope with changing business conditions and manage risks in market conditions are evaluated and proposals are made on the basis of these results in accordance with the Instructions on the Procedure for Organizing Inspections of Banks, Their Branches (Offices), Representative Offices, and Nonbank Credit and Finance Institutions, approved by the NBRB Supervisory Board Resolution No. 8.12, March 30, 2000, and with the Methodological Recommendations on Organizing Inspections of Banks approved by NBRB Board of Directors Resolution No. 209, 


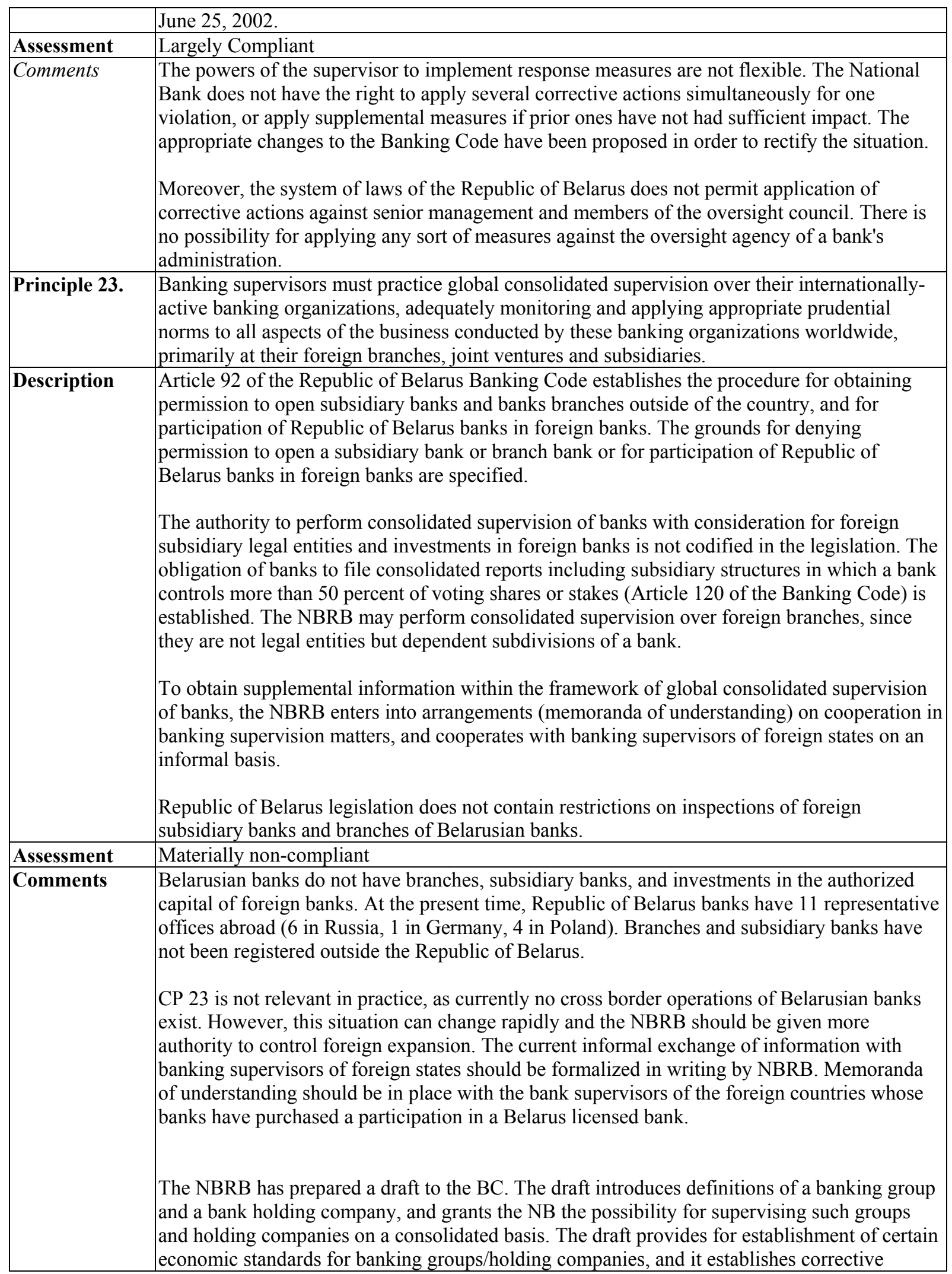




\begin{tabular}{|c|c|}
\hline & $\begin{array}{l}\text { actions to be taken by the NBRB for their violation. Implementation of the draft to the BC will } \\
\text { make it possible to develop and introduce the necessary mechanisms of supervision of the } \\
\text { activities of banking groups and holding companies on a consolidated basis. }\end{array}$ \\
\hline Principle 24. & $\begin{array}{l}\text { A key component of consolidated supervision is establishing contact and information exchange } \\
\text { with the various other supervisors involved, primarily host country supervisory authorities. }\end{array}$ \\
\hline Description & 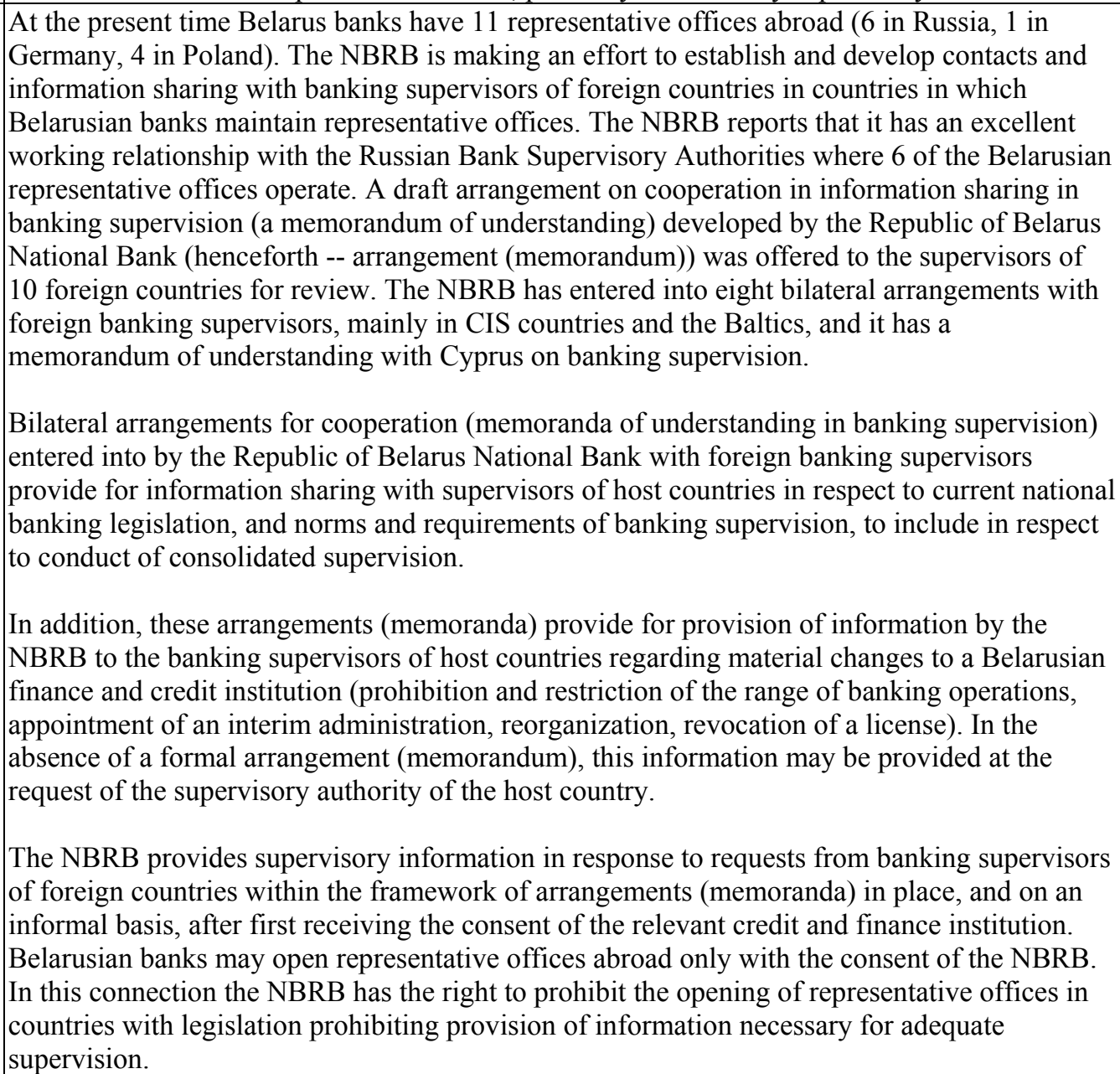 \\
\hline Assessment & Not Applicable \\
\hline Comments & $\begin{array}{l}\text { None of the Belarusian banks have established foreign branches or other structures abroad with } \\
\text { the right to engage in banking operations. } \\
\text { The Belarusian banks have established representative offices in three countries. Request for } \\
\text { information from the control agencies of these countries on the situation of offices of } \\
\text { Belarusian banks abroad is not warranted. }\end{array}$ \\
\hline Principle 25. & $\begin{array}{l}\text { Banking supervisors must require the local operations of foreign banks to be conducted to the } \\
\text { same high standards as are required of domestic institutions and must have powers to share } \\
\text { information needed by the home country supervisors of those banks for the purpose of carrying } \\
\text { out consolidated supervision. }\end{array}$ \\
\hline Description & $\begin{array}{l}\text { Pursuant to the BC, the requirements of Republic of Belarus legislation and regulations of the } \\
\text { National Bank on organizing banking supervision established for banks created on the basis of } \\
\text { Belarusian capital also apply to banks with foreign investments and the subsidiary banks of } \\
\text { foreign banks. }\end{array}$ \\
\hline
\end{tabular}




\begin{tabular}{|c|c|}
\hline & $\begin{array}{l}\text { In keeping with Article } 34 \text { of the BC, the NBRB regulates activities of banks, including banks } \\
\text { with foreign investments and the subsidiary banks of foreign banks, and supervises them. The } \\
\text { prudential requirements imposed on such banks are the same as those imposed on banks } \\
\text { created with Belarusian capital. } \\
\text { According to Article } 110 \text { of the Banking Code, foreign banks, and all banks registered in the } \\
\text { Republic of Belarus as well, are required to comply with economic standards, requirements, } \\
\text { and limits established pursuant to Article } 112 \text { of the code, to classify assets by their reliability, } \\
\text { to form loss reserves for them, and to file reports as established by the NBRB. } \\
\text { The NBRB, prior to issuing a license to a bank that is a subsidiary of foreign owned bank } \\
\text { ensures that the home supervisor has issued an approval. } \\
\text { In accordance with agreements signed with home country supervisors of foreign banks the } \\
\text { NBRB shares information on a reciprocal basis and gives on-site access to the home country } \\
\text { foreign bank examiners to examine the subsidiary; the NBRB has the right to assist the foreign } \\
\text { examiners. }\end{array}$ \\
\hline \begin{tabular}{|l|} 
Assessment \\
\end{tabular} & Largely Compliant \\
\hline Com & $\begin{array}{l}\text { As indicated previously, the NBRB has entered into eight bilateral arrangements with foreign } \\
\text { banking supervisors, mainly in CIS countries and the Baltics, and it has a memorandum of } \\
\text { understanding with Cyprus on banking supervision and the Principle is assessed as Largely } \\
\text { Compliant } \\
\text { The NBRB is pursuing in its efforts to sign an agreement with the Austrian Bank Supervisory } \\
\text { authorities and is currently waiting for a reply to its latest communication. The NBRB reports } \\
\text { it has a signed bilateral agreement with the Central Bank of Russia Sup, and a very good } \\
\text { informal exchange of information system with that Agency. } \\
\text { There is need for the NBRB to further strengthen its assessment of the adequacy of the } \\
\text { reporting systems from a subsidiary bank to the parent and the parent's supervision of the } \\
\text { subsidiary. In addition, there is a need for the NBRB to ensure that it keeps itself well-versed } \\
\text { of developments affecting the soundness of the parent banks and banking groups, that it } \\
\text { remains well informed of the condition of the financial systems of the parent countries, and } \\
\text { that it maintains a close liaison with the parent supervisory authorities. }\end{array}$ \\
\hline
\end{tabular}


Table 2. Summary Compliance of the Basel Core Principles

\begin{tabular}{|c|c|c|c|c|c|}
\hline Core Principle & $\mathrm{C}^{1 /}$ & $\mathrm{LC}^{2} \stackrel{-1}{-}$ & $\mathrm{MNC}^{3 /}$ & $\mathrm{NC}^{4 /}$ & $\mathrm{NA}^{\frac{5 /}{1}}$ \\
\hline \multicolumn{6}{|l|}{ 1. Objectives, Autonomy, Powers, and Resources } \\
\hline 1.1 Objectives & $\mathbf{X}$ & & & & \\
\hline 1.2 Independence & & & $\mathbf{X}$ & & \\
\hline 1.3 Legal framework & & $\mathbf{X}$ & & & \\
\hline 1.4 Enforcement powers & & $\mathbf{X}$ & & & \\
\hline 1.5 Legal protection & & & & $\mathbf{X}$ & \\
\hline 1.6 Information sharing & & & $\mathbf{X}$ & & \\
\hline 2. Permissible Activities & $\mathbf{X}$ & & & & \\
\hline 3. Licensing Criteria & & & $\mathbf{X}$ & & \\
\hline 4. Ownership & & & $\mathbf{X}$ & & \\
\hline 5. Investment Criteria & & & $\mathbf{X}$ & & \\
\hline 6. Capital Adequacy & & & $\mathbf{X}$ & & \\
\hline 7. Credit Policies & & $\mathbf{X}$ & & & \\
\hline 8. Loan Evaluation and Loan-Loss Provisioning & & $\mathbf{X}$ & & & \\
\hline 9. Large Exposure Limits & & & $\mathbf{X}$ & & \\
\hline 10. Connected Lending & & $\mathbf{X}$ & & & \\
\hline 11. Country Risk & & & $\mathbf{X}$ & & \\
\hline 12. Market Risks & & & $\mathbf{X}$ & & \\
\hline 13. Other Risks & & & $\mathbf{X}$ & & \\
\hline 14. Internal Control and Audit & & $\mathbf{X}$ & & & \\
\hline 15. Money Laundering & & & $\mathbf{X}$ & & \\
\hline 16. On-Site and Off-Site Supervision & & $\mathbf{X}$ & & & \\
\hline 17. Bank Management Contact & $\mathbf{X}$ & & & & \\
\hline 18. Off-Site Supervision & & $\mathbf{X}$ & & & \\
\hline 19. Validation of Supervisory Information & & $\mathbf{X}$ & & & \\
\hline 20. Consolidated Supervision & & & & $\mathbf{X}$ & \\
\hline 21. Accounting Standards & & & $\mathbf{X}$ & & \\
\hline 22. Remedial Measures & & $\mathbf{X}$ & & & \\
\hline 23. Globally Consolidated Supervision & & & $\mathbf{X}$ & & \\
\hline 24. Host Country Supervision & & & & & $\mathbf{X}$ \\
\hline $\begin{array}{l}\text { 25. Supervision Over Foreign Banks' } \\
\text { Establishments }\end{array}$ & & $\mathbf{X}$ & & & \\
\hline
\end{tabular}

- C: Compliant.

2/ LC: Largely compliant.

${ }^{3}$ MNC: Materially non-compliant.

${ }^{4 /} \mathrm{NC}$ : Non-compliant.

${ }^{5}$ NA: Not applicable. 
Table 3. Recommended Action Plan to Improve Compliance of the Basel Core Principles

\begin{tabular}{|c|c|}
\hline Reference Principle & Recommended Action \\
\hline 1.2 Independence & $\begin{array}{l}\text { Increase the level of Independence in the Budgetary Process and } \\
\text { increase visibility of Head of Directorate of Bank Supervision }\end{array}$ \\
\hline 1.5 Legal Protection & $\begin{array}{l}\text { Provide legal protection to the Supervisors against legal actions. } \\
\text { Protect Supervisors against legal costs incurred. }\end{array}$ \\
\hline 1.6 Information Sharing & $\begin{array}{l}\text { Formalize the coordination among different agencies involved in } \\
\text { financial sector regulation and supervision }\end{array}$ \\
\hline 3. Licensing Criteria & $\begin{array}{l}\text { Amend legislation in order to permit a deeper analysis of ownership } \\
\text { structure including indirect ownership. }\end{array}$ \\
\hline 4. Ownership & $\begin{array}{l}\text { Decrease the current } 10 \% \text { limit to } 5 \% \text { for authorization of purchases of } \\
\text { shares transferred from original owner to subsequent owners. }\end{array}$ \\
\hline 5. Investment Criteria & $\begin{array}{l}\text { Authorize the NBRB to conduct deeper analysis of the impact of } \\
\text { investments on the bank's financial position. }\end{array}$ \\
\hline 6. Capital Adequacy & $\begin{array}{l}\text { Retain capital adequacy at current level. Implement the disposition of } \\
\text { Instruction 92, taken effect I Jan } 2005 .\end{array}$ \\
\hline 9. Large Exposure Limits & $\begin{array}{l}\text { Give NBRB discretionary power in the interpretation of what } \\
\text { constitutes closely related groups. }\end{array}$ \\
\hline 10.Connected Lending & $\begin{array}{l}\text { Grant bank supervisors the discretion to make judgments about the } \\
\text { existence of connections between the bank and other parties. }\end{array}$ \\
\hline 11. Country Risk & $\begin{array}{l}\text { The effectiveness of Implementation of Instruction } 92 \text { dated June } \\
\text { 2004, that become effective in January } 2005 . \\
\text { Ensure that individual banks have established country exposure limits } \\
\text { and transfer risk limits on their operations }\end{array}$ \\
\hline 12. Market Risk & $\begin{array}{l}\text { The effectiveness of Implementation of Instruction on Economic } \\
\text { Standards for banks on January 1, 2005.can not be analyzed at the } \\
\text { present time. } \\
\text { The banking supervisors have to reach a more proficient level of } \\
\text { understanding market risks and require additional training in order to } \\
\text { analyze and montor the actual level of complexity in the market } \\
\text { activities of the banks }\end{array}$ \\
\hline 13. Other Risks & $\begin{array}{l}\text { The effectiveness of implementation of the Instruction on Economic } \\
\text { Standards for banks due to become effective on January 1, } 2005 . \\
\text { Establish an operational risk management procedure and a procedure } \\
\text { for calculating aspects of interest-rate risks. }\end{array}$ \\
\hline 20. Consolidated Supervision & $\begin{array}{l}\text { The adoption and implementation of a proposed amendment to the BC } \\
\text { will allow the NBRB to develop and introduce the necessary } \\
\text { mechanisms to supervise the activities of banking groups and holding } \\
\text { companies on a consolidated basis. }\end{array}$ \\
\hline 21. Accounting Standards & $\begin{array}{l}\text { Take steps to introduce International Financial Reporting Standards to } \\
\text { the full extent more rapidly than the current timetable provides for. }\end{array}$ \\
\hline 23. Globally Consolidated Supervision & $\begin{array}{l}\text { The adoption and implementation of the draft to the BC that } \\
\text { introduces definitions of a banking group and a bank holding } \\
\text { company, and grants the NBRB the possibility for supervising such } \\
\text { groups and holding companies on a consolidated basis. }\end{array}$ \\
\hline
\end{tabular}




\section{Authorities' Response to the Assessment}

40. The NBRB broadly agreed with the assessment and found it objective and useful for the purpose of further improvement of banking supervision in Belarus, although the NBRB felt that the ratings of several principles (CPs 5, 6, 9, and 21) could have been higher. The NBRB noted that the authorities continue working on the implementation of international standards of banking supervision, including the application of procedures to monitor and to limit country risks, operational risks, and market risks, and that several steps have already been done to implement recommendations formulated by the present assessment. 